University of Louisville

ThinkIR: The University of Louisville's Institutional Repository

Electronic Theses and Dissertations

$5-2009$

\title{
The study of predictive factors of reading in low-performing readers in an urban setting.
}

\author{
Reginald L. Caldwell \\ University of Louisville
}

Follow this and additional works at: https://ir.library.louisville.edu/etd

\section{Recommended Citation}

Caldwell, Reginald L., "The study of predictive factors of reading in low-performing readers in an urban setting." (2009). Electronic Theses and Dissertations. Paper 197.

https://doi.org/10.18297/etd/197

This Doctoral Dissertation is brought to you for free and open access by ThinkIR: The University of Louisville's Institutional Repository. It has been accepted for inclusion in Electronic Theses and Dissertations by an authorized administrator of ThinkIR: The University of Louisville's Institutional Repository. This title appears here courtesy of the author, who has retained all other copyrights. For more information, please contact thinkir@louisville.edu. 
THE STUDY OF PREDICTIVE FACTORS OF READING IN LOW-PERFORMING READERS IN AN URBAN SETTING

\title{
By
}

Reginald L. Caldwell

B.A., Talladega College, 1996

M.Ed., University of Louisville, 2000

\author{
A Dissertation \\ Submitted to the Faculty of the \\ Graduate School of the University of Louisville \\ In Partial Fulfillment of the Requirements \\ For the Degree of
}

Doctor of Philosophy

Department of Curriculum and Instruction

University of Louisville

May 2009 
THE STUDY OF PREDICTIVE FACTORS OF READING FOR LOW PERFORMNNG READERS IN AN URBAN SETTING

\author{
By \\ Reginald L. Caldwell \\ B.A., Talladega College, 1996 \\ M.A., University of Louisville, 2000
}

A Dissertation Approved on

Date April 8, 2009

by the following Dissertation Committee:

Dissertation Director 


\section{DEDICATION}

This dissertation is dedicated to my mother

Ms. Rosemary Dennis

and

all those individuals who have been an important influence to me in becoming the man I am today. 


\section{ACKNOWLEDGMENTS}

I would like to thank Dr. Bonnie N. Marshall and Ms. Veronica P. Wright, for their guidance and patience throughout the years. You both helped me to pursue and achieve a professional goal with your kind, warm and honest "motherly" guidance. Both of you opened the door to this professional journey and I am greatly appreciative.

I would like to thank Spalding University and the University of Louisville faculty and staff for giving me the opportunity to fulfill a lifelong dream. I would like to thank my committee members for their advice, attention and guidance. Your prompt feedback and encouragement were greatly appreciated.

To my mother, Rosemary Dennis and sister, Shawanna D. Coleman, who prophetically stated "God had a plan for me".

Finally, I would like to thank my family and friends for understanding the importance of this goal and their dire support throughout this journey. 


\begin{abstract}
THE STUDY OF PREDICTIVE FACTORS OF READING IN LOW-PERFORMING READERS IN AN URBAN SETTING
\end{abstract}

May 9,2009

The middle school years are most difficult because students now have to use reading to learn in all content areas. Low-performing students who daily face reading difficulties in school often feel helpless in their desire to become better readers and may develop poor self efficacy toward reading. Furthermore, these students may experience reading failure at a higher rate than their same age middle school peers. The current study examined two reading programs, Read 180 and Corrective Reading, and the impact they have on the self-efficacy of 216 middle school students. The results provided information regarding what factors of self-efficacy improved reading. Also, the results indicated that Read 180 program provided statistically significant results leading to positive change from pretest to posttest for low-performing middle school students in one of the schools. 


\section{TABLE OF CONTENTS}

ACKNOWLEDGMENTS...................................................

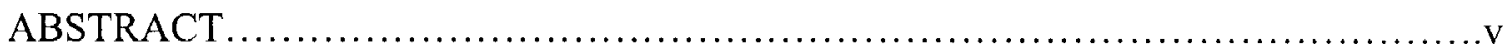

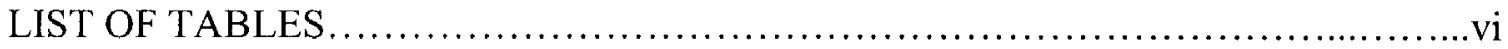

Matrix for Collection of Data for each Question................................. 3.1

The Reader Self-Perception Descriptions........................................ 3.2

Research Project and Task Timelines......................................... 3.3

Point Value for the Reading Self Perception Scale Scoring Key....................... 3.4

Average Mean Score for the Four Factors Associated with Reading Self-Efficacy.....4.1

Score Interpretation of the Reader Self-Perception Scale........................... 4.2

Reliabilities for Each Scale.................................................. 4.3

Dependent Sample Statistics for Corrective Reading and Read $180 \ldots \ldots \ldots \ldots \ldots . . . . .4$

Dependent Sample Statistics for Corrective Reading.............................. 4.5

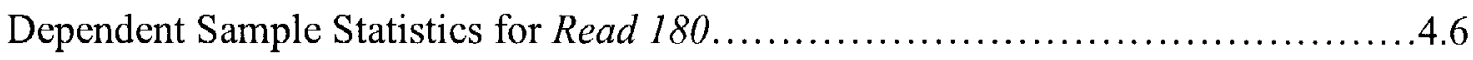

Thirteen Predictor Variable for Reading Improvement, ...........................4.7

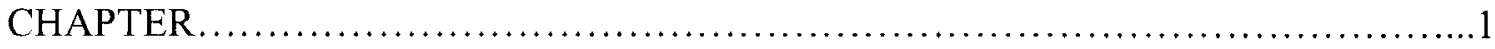

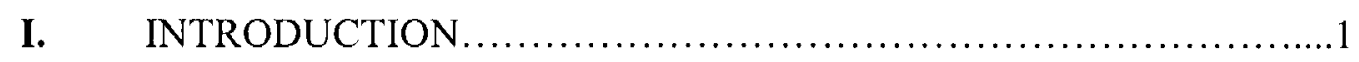

Mandate for Improvement.........................................

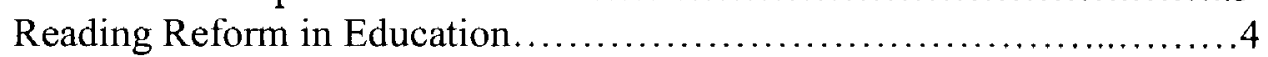

Reading and Literacy...............................................

Kentucky Education Reform.........................................6 6

Jefferson County Public Schools Response to the Achievement Gap......8

Literacy, Access and Funding for Low-Performing Students..............10 
Low-Performing Students and Self Efficacy........................12

Self-Efficacy and Literacy....................................... 14

Self-Efficacy, Learning and Reading. ................................. 15

Reading Remediation................................................ 17

Reading Programs................................................ 18

Summary .................................................... 20

Purpose of the Study..............................................21

Research Questions.............................................22

Definition of Terms..............................................23

Assumptions and Limitations.....................................23

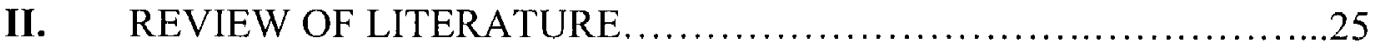

At-risk Students...................................................25

Low-Performing Student Background................................. 27

Parental Involvement..............................................30

Academic Motivation in Self-Efficacy............................... 32

Reading Remediation................................................37

Parenting in Low-Performing Students..............................42

Learned Helplessness.................................................44

Student Achievement..............................................47

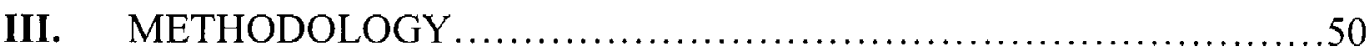

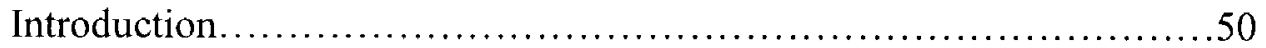

Sources of Data................................................. 52

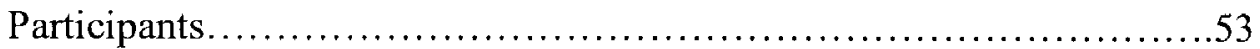

Schools..................................................... 53

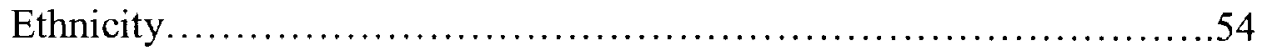

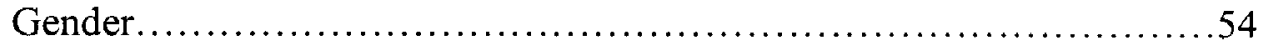

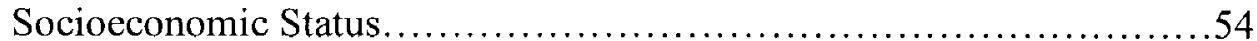

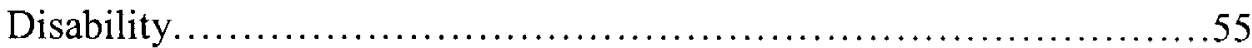

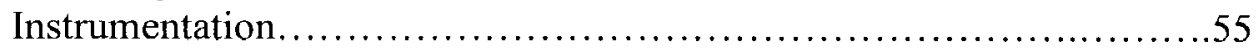

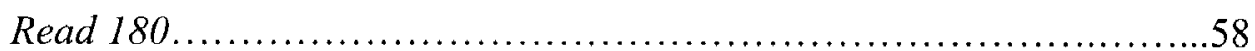

Corrective Reading................................................ 58

Research Questions...............................................60 
RESULTS.

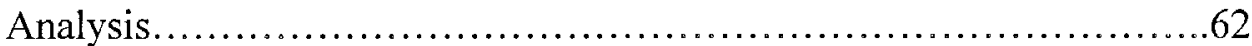

Results of Current Study ..........................................662

Preliminary Analysis..............................................62

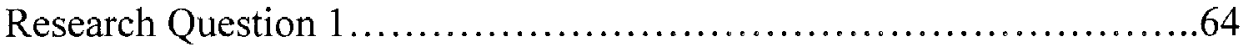

Research Question 2.............................................67

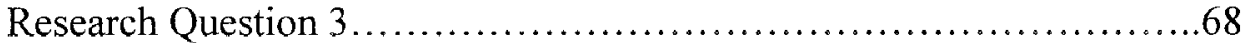

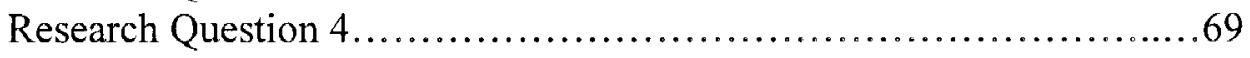

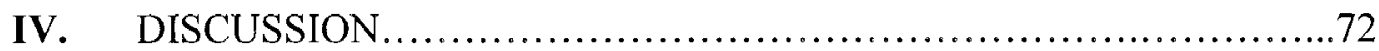

Internal and External Threats..................................... 75

Recommendations for Future Research.............................75

Conclusion......................................................... 78

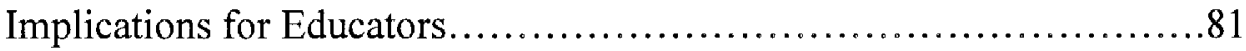

The Importance of Qualified Teachers..............................81

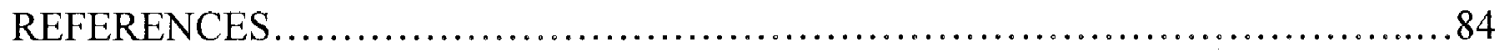

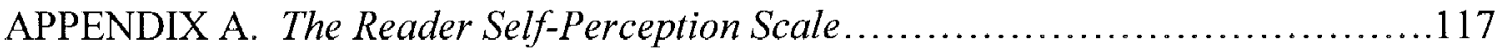

APPENDIX B. The Reading Self-Perception Scale Directions......................119

APPENDIX C. Regression Percentage Improvement Using Read 180 and Corrective Reading.....

APPENDIX D. Regression Percentage Improvement for Read $180 \ldots \ldots \ldots \ldots \ldots \ldots . \ldots 121$

APPENDIX E. Regression Percentage Improvement for Corrective Reading...........122

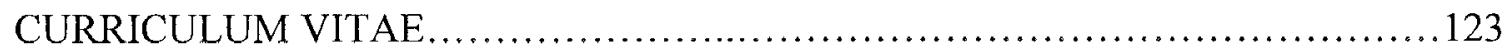




\section{CHAPTER I}

\section{INTRODUCTION}

In the last six years, there has been an effort by the federal government to more explicitly address the disparities in public education. There is no example more evident than the passage of the No Child Left Behind Act (NCLB) of 2001, in which, the focus on closing the achievement gap has become a major priority of our nation. Reading educators all agree that for the literacy achievement gap to shorten, there has to become a nationwide focus on literacy $(\mathrm{Au}, 2003)$. Children who are raised in homes where education is modeled and valued prior to entering early school year"s "demonstrate higher levels of competence, achievement, social development, self esteem, and mental health" (Govender \& Moddley, 2004, p. 37). The dispositions and attitudes about learning are evidenced by "parental warmth, acceptance, inductive discipline, and non punitive disciplinary practices" (Govender \& Moodley, 2004, p. 38) in children who value education.

Kentucky, like other states, has an achievement gap that persists among its students (KDE, 2002). The basic premises of KERA were to equalize the disbursement of funds to all school districts, rich or poor, in Kentucky so that all children would receive a sufficient education (Alston, 1999). Unequal disbursement of expenditures has led to a gap in access to employment opportunities, education, and social isolation that impacts the progressive economic growth of Kentucky. 
Banks (2005) identified macrocultures, and microcultures that influence human behavior. His model demonstrated how influential teacher perception of the student impacts their sympathy toward the child's academic success. In the past, student achievement was not a measurement for holding schools responsible for adequate educational progress. Having an accountability system in place would assure that measurements based on quantifiable evidence could provide a numerical predictor of the school's performance (Beverly, 2002, p. 7). Past measurement of school performance was based on the logic of confidence (Meyer \& Rowan, p. 357) paradigm which believed that if variables such as professionalism of the staff, student's own responsibility for learning and lack of responsibility of teachers to raise performance of students were not the teachers concern, then schools would not have issues meeting standards. (Beverly, 2002, p. 8). Accountability measures would eliminate these presumptions from the psyche of faculty and staffs. Research states that a school's instructional content and expectation of student academic performance are all predictors of low-performing student success (Cohen, Kincaid \& Childs, 2007). Additionally, factors such as school climate (Kober, 2001), instruction that includes the low-performing student population culture (Kourea, Cartledge \& Musti-Rao, 2007), and the perception of the low-performing students learning by the teacher (Gushue, Clarke, Pantzer, Scanlan \& Kolone, 2006), all are important considerations in increasing student learning.

Considerable improvements have been noted in the performance of students since KERA. Studies (David,1999) Kannapel, Augaard, Coe, \& Reeves (2001), Pogio (2000) Roeder (1991) reported that increase in test scores of students in Kentucky are notable, but the gaps between low-performing students and their same age middle class peers still 
exist (Moore, 2001). It is interesting to note that discrepancies in achievement of lowperforming students are still evident. Furthermore, data reveal that testing gaps still persist between black and white students, with females out performing male students (Smith, Neff, \& Nemes, 1999). The National Assessment of Educational Progress (NAEP) reported that Kentucky had made significant progress between 1992 to 1998 . Unfortunately, current research consistently shows that low-performing schools continue to lag behind schools in higher socio-economic areas (Poggio, 200; Roeder, 1999). These same disparities are comparable to school districts throughout Kentucky. Mandate for Improvement

Since 2002, there has been an effort in Jefferson County Publics Schools in Louisville, Kentucky to explore ideas for improving public education. The leadership of Greater Louisville Incorporated concluded that in order for the city of Louisville to continue its growth and to be competitive with other major urban metropolitan cities Louisville needed to improve the education of its future workforce (JCPS, 2003). The Greater Louisville Report on Education (2003) reported that Jefferson County Public Schools is the $29^{\text {th }}$ largest school district...in the U.S. (p.4). Although there has been a decrease in dropout rates and an increase in the number of schools being rated among the top tier schools in the state, the report indicates there are significant issues that exist regarding academic performance specifically in the area of literacy. Of the 96,500 students who attend Jefferson County Public schools in 2001, 17,667 students are not reading at grade level (GLI report, 2003). 


\section{Reading Reform in Education}

The No Child Left Behind Act (2002) is a reaction by the public and political organizations to require schools and educational agencies to be accountable for using public funds (NCLB, 2002). However, teachers have witnessed the pressure from policymakers to use research-based methods of instruction when teaching students to read and write (Farstrup, 2002). Equally important, pressure has come from the public, politicians, and the press to prevent the possibility of ineffective access to public education by all sectors of our democratic society (NCLB, 2002). To prevent this ineffectiveness and to gain the public's trust, measures were needed to regain the trust of the educational community concerned with public education.

The impact of NCLB (2002) is being felt by school districts in the United States and is changing the approach to literacy by schools. NCLB's goal of accountability through reading is witnessed in the government's effort by using funds for the Reading First initiative. Together with Reading First monetary support, states have implemented research-based measurements that are valid and reliable for assessing reading accountability. Furthermore, these assessment instruments are coupled with research based reading instruction for all students. Additionally, failing schools receive this grant for three years and the expenditures can be used for teacher education programs, remedial program materials, as well as, assessment tools that monitor the progress of students in the program.

Although increased accountability using scientifically based research has become the emphasis in public education, there still are factor's that teacher's cannot control regarding student learning and student achievement. These factors include: the ecology 
of the school environment, being able to select preferred students, factors outside the school environment that impact student learning and behavior change agents that control students' attitudes regarding learning (Stewart, 2004). Because of these and other factors, teachers in the classroom must use research based strategies to engage greater numbers of students in optimal learning for the period of time instruction occurs within the classroom (Bracy, 2005).

As a result of factors that may impede learning, teachers must also understand that teaching styles, strengths, areas of growth, personality, beliefs and values all contribute to the learning atmosphere within the classroom. Regardless of student learning differences, teachers must respect students, treat each student as an individual and most importantly, have a high level of expectation that will be maintained throughout the curriculum implementation and during instruction and assessment (Szabo \& Mokhtari, 2004).

Reading and Literacy

For low-performing preschool students to have success in school and for equal employment opportunities later in life, they will have to access to the "phonemic awareness, graphophonemic knowledge, word recognition, fluency, vocabulary, and comprehension" (Mathes, Durodola, Hagan, Thompson, \& Vaughn, 2007, p. 261) skills for reading and writing. Alexander and Entwisle (1998) have conducted research that supports their thesis that state "the academic difficulties experienced by many minority youngsters are peculiarly traceable to adjustment problems and patterns of underachievement that begin in the first years of formal schooling" (p.3). 
It should be noted that K-3 low-income children benefit from placement into comprehension strategy instruction reading programs (Sweet \& Snow, 2002; Taylor et.al., $1999 \&$ Newman, 2001) which focus on recognition of contextual information (Palmer \& Stewart, 2003; Moss \& Newton, 2002). For this reason, research consistently reported the importance of preschool in the developmental process of literacy for lowincome minority students. To illustrate, it was found in the Title I Chicago Child-Parent Centers' study (Reynolds, Temple, Robertson, \& Mann, 2001) that 29\% of the preschool students who attended had higher graduation rates; $42 \%$ were less likely to be arrested for violent offenses; and $42 \%$ had lower retention rates than those peers who had not attended preschool prior to ages 20-21. Alongside this study, is significant evidence that supports the importance of Head Start in reducing the score gap in low-performing students in the areas of literacy and vocabulary (Kavale \& Furness, 2000). Kohn (1999) reported that students in early intervention programs are desperately in need of literacy development. Sixty percent of children in public education under age five receive services in an early intervention programs (Eccles, Lord \& Buchanan, 1996). Research also shows that the quality of instruction in these programs needs to be redefined for adolescence to be prepared for literacy (Unrau \& Schlackman, 2006). Furthermore, there is evidence that points to a lack of preparedness by childcare workers to efficiently engage children in early literacy activities related to reading (Girolametto, et.al, 2007, p. 75). Introducing childcare workers to decontextualized language instruction, strategies that encourage thinking and problem solving and print concepts are all essential to the instruction in child care facilities. Besides introducing proper reading instruction, the 
introduction of culturally relevant reading material to students is also vitally important (Finn, 1999).

Furthermore, Connecticut Commissioner of Education Sternberg and Grigorenko (2000) wrote that closing these gaps among children prior to entering kindergarten provides an opportunity to close these deficits that increasingly present themselves over the child's academic life.

In the examination of the history of U.S. education, there needs to be better understanding of the implications of race and its impact on student learning. In addition to the expertise of policy makers and school administrators, teachers should have a knowledge base that will enable them to evaluate how this historical issue has affected teaching, policy, and procedures in schools and classrooms (Shealey \& Lue, 2006). This information, analyses, and reflection may lead to answers of why students of high poverty backgrounds are disproportionately turned off from learning. It should also be noted that when low-performing students see less of themselves in the curriculum and thus begin to perform poorly academically; "students of color and those from impoverished settings [historically become] the primary consumers of special education services (Shealey \& Lue, 2006, p. 4). As these practices persist, policy makers and those accountable for administration in school districts will have to ask if there is a deliberate attempt to place students of color in special education, where some assert that academic curriculum has consistently prepared these students to be minimally equipped for success in life, and at worst, housed in prison industrial complexes (Shealey \&Lue, 2006).

Combined with factors including early preschool intervention for students with reading difficulties, partnership of teachers and parents involvement in closing the 
achievement gap for low-performing students, must be developed for the academic wellbeing of students (Housego, 1992). Vondra (1999) believes that these relationships are "the basis for learning" (p. 164). Educators have to understand the responsibility low income parents, in their effort to find quality education in the most challenging socioeconomic circumstances, entrust in a school: their child's educational future with teachers. As well, teachers have to instill in low-income students an expectation that is one of advocacy and free from negative biases that discourages the learning process. Banks (2005) reported that teachers who encourage a culture of low expectation communicate a sense of doubt in the minds of low-performing students, who later, perceive that they are inadequately prepared to attend colleges and universities after high school.

\section{Jefferson County Public Schools Response to the Achievement Gap}

The Louisville Urban League's report, The State of African-American Youth in Metropolitan Louisville (1999), highlighted the hurdles faced by Kentucky in order to ensure equitable access to education in all classrooms. While "superficial changes [have occurred with accountability] (...) it is apparent that much has remained the same within the classroom" (Urban League Report, 1999, p. 44). Poorly qualified teacher training in reading, high teacher attrition rates, unmotivated students, and poor administrative staffs in low-performing schools, all contribute to the climate of a school at-risk of decreasing the self-efficacy of their students in reading.

The attainment of education by the lowest-achieving students in the Jefferson County Public Schools is essential for the city of Louisville to reach its full potential. The Brookings Institute report titled Beyond Merger: A Competitive Vision for the 
Regional City of Louisville (2002), stated that in order for a true merger [metro with suburban governments] to exist that the educational level and the attainment of technological skill are pertinent to the future growth of the metro area. This goal may be accomplished in low-performing schools if reading is made a "priority in both the classroom and school level" (Taylor, Pearson, Clark \& Walpole, 1999). Therefore, literacy programs that focus on moving the 17,667 (approximately 18 percent) of the 96,500 students in JCPS out of the novice-category or low-performing category of learners is essential (Report on Education, 2003, pg. 6).

Factors that contribute to the achievement gap in the JCPS schools include the large school and district size, the large percentage of urban versus suburban poverty levels, student diversity, and the systematic management of a "managed-choice/magnet system"(Moore, 2002, pg. 25). JCPS has made efforts to identify and mend achievement gap concerns among its pupil population (JCPS, 1999a).

Recently, JCPS has begun to implement strategies to reduce gaps in achievement of students. One particular plan required teachers to target students who were low performing. Teachers would then create individualized strategies and implement them into their instruction to address these issues of students' academic struggles in the areas of reading, writing and mathematics (JCPS, 1999).

Alongside local education agencies to support this version were the Kentucky Department of Educator's Minority Student Achievement Task Force and the Louisville Urban League. These organizations were crucial in requesting, analyzing and sharing data needed to address the issue of the achievement gap (Moore, 2002, pg. 26) in the Louisville metro areas, and specifically, in JCPS. Based on the above, JCPS 
administrators were better prepared to address and implement plans to confront the complexities of the local achievement gap by analyzing data, providing staff development and introducing research based strategy instruction to lessen the achievement gap. Surprisingly, the district appears to be using crucial, data-based evidence on P-12 student achievement information to better address the needs of schools, teachers, staff, and most importantly students.

Literacy, Access, and Funding for Low-Performing Students

There are numerous and documented definitions of literacy. Winebrenner (1996) defines literacy as "the ability to make meaning from printed words." Additionally, Winebrenner states:

good readers automatically use strategies to adjust their reading rate to the material and check to see if what they are reading makes sense. Poor readers don't even know that such strategies exist. They think that good readers were "born that way" (p. 79).

In relation to the topic of the present study, a significant explanation for such comments can be explained, in part, by the often documented inability of low-performing students to access literacy material within their communities that allows them sufficient printed books, optional topics, adequate reading material, proper areas for reading (Neuman \& Celano, 2001). More important, low-performing students between the ages of 3-5, when the introduction to reading is essential are documented in the literature as less likely to be read to at a key moment in literacy development (NCES, 2001). This issue is not as existent in middle-income homes where students' access to print rich material is more widespread. 
The National Assessment of Educational Progress (NAEP, 1995) illuminates that such disparities in early preschool grades have a profound effect on students' reading scores especially by the fourth grade. Further, Miao, Darch, and Rabren (2002) conducted research that found evidence that low-performing readers in the elementary school grades will not improve academically and will not enjoy school nor reading if these deficits are not addressed (Kamps \& Will, 2001).

Another significant factor related to reading failure pointed to the over-reliance on televisions in low-income child care centers to circumvent reading instruction. These centers as reported by Neuman and Celano (2001) were not likely to have areas for reading books, materials at children's interest-levels, or age appropriateness of reading titles. Consequently, a published report by the International Reading Association (IRA) Making a Difference (2000) recommended that schools should have funding which allows two new books for every student each year located in the school library and that every school library provide twenty books per child. Foundationally, there should be seven books per child for every classroom library, with one additional book added each year.

Torgesen (1998) asserts "the best solution to the problem of reading failure is to allocate resources for early identification and prevention" (p.32). Empirical research publications and data from large-scale policy reports are clear that students, who experience literacy deficits from preschool to second grade, will continue to fall behind in literacy achievement (Francis, Shagivity, Stuebring, Shaywitz, \& Fletcher, 1996; Torgesen \& Burgess, 1998). Identifying low-income students in the middle elementary school grades is typically too late. The earlier low-performing students are identified as 
having literacy achievement deficits, the more likely their literacy strengths can be targeted, the more benefit can occur from successful intervention programs (Craig, Connor \& Washington, 2003). Low-income students who are performing "below the average range in basic reading skills at the end of first grade may be reduced dramatically through the provision of high-quality instruction (Lyon, Fletcher, Fuchs, \& Chabra, 2006; Mathes \& Denton, 2002; Torgesen, 2000). Equally important is that achievement gaps will continue to widen, particularly at the time students enter middle school, but this evidence is also documented, in general, for students as they move (Jencks \& Phillips, 1998) from elementary school entry through $12^{\text {th }}$ grade (Phillips, Crouse \& Ralph, 1998). This is particularly the case if literacy intervention does not take place in the early elementary school years.

Low-Performing Students and Self-Efficacy

Most students who are considered low income in the United States are minorities including students who are of African, Hispanic, and Native American ethnicities (Lee, 2002; Talbert-Johnson, 2004). Minority students consistently show higher incidences of low academic performance than do their White and Asian counterparts (Lindo, 2006). These incidences have long-term effects on "one's later life chances, such as, education earnings, employment behavior, and health" (Yeung \& Conley, 2008, p. 303). This gap in the academic performance of low-performing children has been a consistent contributor to what is known as the achievement gap (Lee, 2002; Talbert-Johnson, 2004). Children who are products of the achievement gap "score significantly lower in reading and writing than children from middle and high income backgrounds (Teal, Paciga \& Hoffman, 2007, p. 344). This growing disparity among low income minorities has caused 
states to work toward making progress in closing these gaps (Lindo, 2006) in urban schools or "make rapid, sustained progress toward doing so" (Miller, 2003, p. 3). In fact, studies indicate that student access to reading material is a predictor to success in literacy (Neuman \& Celano, 2001), without reading access, students in urban schools will have significantly larger reading achievement gaps than the general student population (Teale, Paciga \& Hoffman, 2007). Research based practices focused on building the selfefficacy of low-performing students through literacy can have a powerful influence on reading motivation (McCabe, 2006). In that vein, research has revealed that a child's lack of motivation to read has a direct correlation "with a decline in belief in their ability to read" (Bogner, Raphael \& Pressley, 2002).

Equally important, is the lack of research regarding the importance of how "selfefficacy beliefs are related to academic performance and self-regulated learning" (Henson, 2002, p. 137) of low-performing readers in public education. Sanchez and Nichols (2007) propose that "[students] may avoid or exert less effort in situations about which they possess a lower level of self efficacy" (pg. 8). Deficits in the area of selfefficacy lead students to what Thomas and Gadbois (2007) call self-handicapping where students "see task performance as a reflection of themselves" (pg. 102) which therefore lead to negative attitudes about reading (Dennis, 2008).

Through the use of achievement data schools are now better prepared to address deficits in reading. With the understanding that certain factors lead to consistent reading problems, attention has now been paid toward addressing these factors. Educational response has increasingly begun to examine the importance of self-efficacy and reading as crucial elements in addressing the reading achievement gap. These finding have led 
researchers to examine the importance of developing self-efficacy traits in students that lead to reading gains.

\section{Self-Efficacy and Literacy}

Bandura (1997) is documented as first theorist to use the term self-efficacy in the literature. Bandura defined self-efficacy as "belief in one's capabilities to organize and execute the course of action required to produce given attainments" (1997, p. 3). "An individual's belief about him-or herself [is] a strong influence on behavior" (McCabe, 2006, p. 253). In that light, low-performing students who are " $40 \%$ more likely to read below basic skill level" (Donahue, Finnegan, Lutkus, Allen, \& Campbell, 2001) are more likely to have low motivation in their ability to read (Bogner, Raphael \& Pressley, 2002). "Self-efficacy beliefs are a powerful influence on [students'] motivation" (McCabe, 2006, p. 253). Self-efficacy beliefs among low income minorities "who judge themselves as lacking" (Bandura, 1986, p. 220) in the ability to read "will [contribute to behaviors that] avoid reading rather than [cause students to engage in behaviors from which they will] experience failure and frustration" (McCabe, 2006, p. 253). Low-performing students who have reading problems are typically unaware of how to judge their progress in reading (Schunk, 2003, p. 164). Simply stated, "for learners to evaluate their progress, it is essential that they receive goal progress feedback (Schunk, 2003, p. 164).

Additionally, when progress feedback, including formative and summative, is used, student's are able to enhance "their self efficacy for further learning (Pintrich \& Schunk, 2002, p. 148). This, in turn, contributes to self-efficacy and students' developing and maintaining motivation for literacy learning. 
In the same manner as the above sources reported the connections between selfefficacy and reading, there is a considerable amount of research that points to employment choice and low self-efficacy is indirectly connected to career indecisiveness of large numbers of low-performing students (Lease, 2006). The most important information about career decision-making confirmed that there is a relationship between positive versus poor vocational identity and adaptive career beliefs (Bigler, Averhart \& Liben, 2003), fear of commitment (Minor \& Jepsen, 1991), and career exploratory behavior (Womble, 1995) in students who struggle with academic, and in particular, literacy development.

One major point that should be emphasized from the above, summarized research is that self-efficacy is connected to literacy and future employment choices of lowperforming students. For low-income students to access higher education, employment opportunities, life opportunities, and to earn competitive salaries, intervention in the early stages of literacy is important for students in increasing their self-efficacy.

\section{Self-Efficacy, Learning and Reading}

Bandura (1989) explains there are three components involved in human performance, the individual, the environment and the outcome. Barkley (2006) adds that the environment in which an individual is nurtured has a profound impact on outcomes of their performance. Those who grow up in environments where they consistently are able to perceive their "capabilities for learning [and] or performing actions at [high] levels" (Schunk \& Zimmerman, p. 7) are likely to have positive self-efficacy beliefs. When the performance of the individual is consistently marked with failure, overtime, cognitive and motivational variables suffer (Schunk \& Zimmerman, 2007). Self-fulfilling prophecies 
are persistent in poor self-efficacious students that lead to a cycle of learned helplessness and failure (Margois \& McCabe, 2006). Struggling readers with low self-efficacy may often fake illnesses, sleep during instruction, sweat profusely, have off task behaviors, and/or complete reading assignments carelessly to avoid having to participate in reading instruction because of low self-efficacy (Pritzlik \& Chan, 2007). These escape behaviors cause the reader to avoid reading in other academic activities, which eventually impede reading and overall achievement. Poor self-efficacious students eventually "exacerbate deficits and create additional school difficulties, such as poor grades, conflict with teachers, lower track placement, special education placement, failure on high-stakes testing, and retention" (Margois \& McCabe, 2006, p. 219). To get students to begin reading to learn, educators have to motivate students to "engage in task and achieve when they believe they can accomplish the task" (Linnebrink \& Pintrich, 2003, p. 134). Environments where the individual lives and/or is educated can impact self-efficacy, especially, if it encompasses positive and encouraging feedback. This feedback is a crucially important influence on "choice of activities, effort expenditure, persistence, and achievement" (Schunk \& Zimmerman, 2007, p. 3). Students with increased self-efficacy will participate in individual and classroom activities and will engage difficult task longer until they are complete. Self-efficacious students are able to monitor their own progress, in comparison to other students, and rate their level of performance as high. These students, if they are having difficulty, are self-efficacious enough to call upon past learning strategies that were successful in helping their completion of difficult task. Selfefficacious students can differentiate appropriately when they use models that present the characteristics associated with self-efficacious people. Self-efficacious students are 
knowledgeable in deciphering discrete persuasive information (i.e., progress monitoring, self-feedback, observational comparison, physiological states) as motivation to perform to the best of their ability on difficult tasks.

\section{Reading Remediation}

"There is little debate among researchers, policymakers, and educational stakeholders that reading achievement among [low-performing] students is an important issue" (Flowers, 2007, p. 424). Early intervention of reading failure must be implemented during the primary grades rather than waiting until students are reading two years below grade level when intervention is too late and students are "at risk" for reading failure (Nagakoa \& Roderick, 2004). Early readers who are unable to attain word reading skills, fluency, vocabulary development, and have poorly trained teachers will continue to have serious reading problems. Further, schools and teachers are blamed indirectly for the failure of students to learn based on factors that are not in their control, such as, "poverty, English as a second language, [and] poor attendance" (Papalewis, 2004, p. 24) and high student dropout rates.

Studies have shown that the type of reading material accessible to young lowincome children is crucial to their reading development (Walker \& Dalhouse, 2005). Studies have indicated that students who grow up in low-income environments are least likely to have "resources for [prevention].... early identification and prevention" (Craig, Connor \& Washington, 2003, p. 31) of reading failure. Research has indicated that "on average middle income children had 99 percent and 99.8 percent more books at home than the lower and lowest income students, and 86 percent to 88 percent more books in 
their classroom libraries than lower and lowest income students respectively" (Dalhouse, 2005, p. 157).

To assist educators in the remediation of reading deficits, promising research has pointed to the importance of researched based reading programs as one of many viable solutions. Direct instruction programs are research based reading programs that provide remediation in core academic areas. These areas include reading, writing, math, language arts and foreign language. Because of the scientific research involved in the process of creating the format for direct instruction reading programs, individual school districts and federal programs that provide funding for school districts to implement these programs are confident in the rigor and science behind its etiology.

\section{Reading Programs}

Follow Through is a program created by the federal government. Its purpose was to measure the impact of direct instruction programs in other school districts in the United States from 1967-1995. Their conclusion indicated that the reading achievement of students who participated in direct instruction reading programs was excellent in improving reading, math and thought processes of students participating. Additionally, students who participated showed higher gains than control groups, higher rates of attendance, few behavior problems, and were least likely to drop out of school.

The components of direct instruction include:

1. The likelihood of a student not remediating or improving their reading ability is not likely because of the rigor involved in testing the methodology of direct instruction. 
2. Although there have been arguments regarding whether direct instruction is prejudice in its targeting of low-performing students, that it stifles the creativity of teachers, and does not allow students to generalize their new reading strategies to other content areas, direct instruction does not involve rote learning.

3. The development of three critical areas are essential to the success of direct instruction; assessment of the behavior of students, progress feedback from the teacher to student, as well as, student to teacher. (Carlson \& Francis, 2002) The success of direct instruction reading programs is predicated upon the relationship between the teacher and the student. Such relationships can foster a better understanding of the issues that impede the reading improvement of these students. Teacher "with-it-ness" (Kounin, 1970) during instruction will allow for a faster response to reading problems during instruction. Further, the teacher can use assessment instruments included with direct instruction programs to monitor progress. Also, as the teacher provides feedback through observation and assessment, the student will begin to address their areas of weakness through self-feedback. Self-feedback monitoring entails how to communicate to the teacher when they are not comfortable moving forward in the lesson in direct instruction if the student feels they are not at the mastery level.

Read 180 is a researched based direct instruction reading program developed by Vanderbilt University. A piloted Read 180 program was used in Orlando, Florida which consisted of 10,000 students who witnessed significant growth in their reading and overall improvement of self-efficacy toward reading. Read 180 was designed to correct reading flaws for students in grade four through eight by using direct instruction reading strategies taught to the teacher. 
Like Read 180, Corrective Reading is specifically designed for students who have a need for reading remediation in grade three through eight. This program ensures that there is consistency in the delivery of reading instruction to students by the use of a scripted curriculum, which also does not allow for teacher instructional flaws. Both programs have been identified as increasing the reading level and self-efficacy of student's labeled behavior disordered and learning disabled (Strong, Wehby, Falk \& Lane, 2004).

By reducing class size, implementing technology, small group read aloud, addressing the importance of the physiological makeup of the classroom to make reading comfortable and longer class periods that deal directly with intensive reading instruction, student reading improvement is inevitable according to the research by Papalewis (2004).

\section{Summary}

Since the publication of A Nation At Risk (1983), reform has been an ongoing endeavor of many state departments of education. Research studies and reports illuminate that there has been evidence of some success in this regard, in Kentucky with the implementation of Kentucky Education Reform Act (KERA, 1990). However gaps still persist between poor and middle class students in the state. Questions still remain unanswered if Kentucky "reinforces rather than compensates for differences in students" family background" (Zigler \& Stephenson, 2007, p. 175) Increased attention to early childhood education, access to quality teachers, high quality reading and writing instruction, and research based teaching strategies, strongly increase academic performance. Nevertheless, limited access to these materials impedes the objectives of No Child Left Behind (2001) and KERA (1990). 
This present study contributes to the above policy and education literature in that it examined the relationship between self-efficacy and reading success of students in remedial middle school reading programs in a large urban school district in a southeastern state. Findings from this study will contribute to the knowledge of educators of what factors are important to consider to increase reading gains of lowperforming students in middle school settings.

\section{Purpose of the Study}

The present study examined the influence of remedial reading programs on the self-efficacy of 223 low-performing readers in grades six through eight in the Jefferson County Public Schools [JCPS] in Louisville, Kentucky. Student success is measured by the students' improvement on individual reading inventories (IRI) and self-efficacy scales.

While current research studies have addressed reading achievement through the use of empirical data, it appears that few have offered insight into reader's individual self-perceptions. Recent scales of reading achievement have failed to address the following (Henk \& Melnick, 1995):

1. Lack of scales used to address self perceptions of overall content achievement or proficiency in language arts have addressed reading achievement specifically. (p. 472)

2. Scales lacked test question items that directly measured self-efficacy. (p. 472)

3. Prior scales did not meet the appropriate sampling, therefore voiding the norming standards appropriate in research. (p. 473) 
4. Prior scales were not grounded in the learning theories, thus lacking the appropriate research to match its measurement. (p. 473)

5. Reading assessments do exist that measure self perception of low-performing readers qualitatively, however, due to the fact they are administered individually, the assessments are thought of as too time consuming and are not practical in their implementation. (p. 473)

6. Scales that fail to measure key reading elements of reading achievement such as comprehension, fluency, word analysis, and word recognition. (p. 473).

The overall purpose of this study was to discover and compare the effects of individual low-performing readers' self-perception of their individual reading achievement and the predictors of reading improvement.

\section{Research Questions}

The research questions in this study address a comparison of the effects of individual low-performing readers' personal judgments of their individual reading achievement and the perceived effects of self perception on students' reading performance. Analyses will address individual student's reported perceptions of selfefficacy regarding reading. Different levels of self-efficacy will be analyzed separately since self-efficacy may be categorized as having four distinct categories that are impediments to students' reading success.

\section{Research Questions}

At the middle school level:

1. Is there a difference between Read 180 and Corrective Reading on the reading improvement of Individual Reading Inventory (IRI)? 
2. What are the factors that predict reading improvement?

3. What are the factors that predict reading improvement using Read 180 ?

4. What are the factors that predict reading improvement using Corrective Reading?

The criteria for the methodology to answer the present study's research questions are described in Chapter III, including participants, procedures, and instruments and methods of analyses.

Assumptions and Limitations

This study is a quantitative study designed to examine if relationships exist between self-efficacy and reading success for students in two remedial reading programs in the Jefferson County Public School system. Since this study was conducted in this district, it may not provide an explanation for the reading disparities in the surrounding counties in Kentucky or elsewhere. Factors that may be responsible for the lack of reading success for other students in Kentucky vary dependent upon socioeconomic and other educational issues. Other factors that may cause limitations in generalizability include language, culture, ethnic group, literacy, period of time in the school system, and/ or perception of parental or guardian involvement (Boulay, 2005).

\section{Definition of Terms}

Individual Reading Inventory: assessment instruments used to record data on the students past, present and future readability levels.

JCPS: The Jefferson County Public School system in Louisville, Kentucky is recognized as the $29^{\text {th }}$ largest district in the nation. JCPS is composed of 152 schools with 96,500 students. 58 percent of the students in the Jefferson County Publics School 
system are white and 36 percent are African-American. 3,433 students are classified as English as a second language (GLI, 2003).

Novice: According to state department of education standards, "learners in the school system who are not moving properly toward proficiency. A novice is the lowest CATS test score category." (KDE, 2002).

Reading at Grade Level: Based on state department of education and JCPS standard, reading at grade level signifies a student who has CATS score of "apprentice" or a standardized (Stanford or CTBS) test score of at least "4" (on a scale from 1 to 9) (KDE, 2002).

Remedial Reading programs: Reading intervention programs are adopted and are provided by experienced teachers during the regular school day to address student reading deficiencies in the area of decoding, fluency, phonemic awareness and whole language. Students are chosen based on their performance on standardized reading assessments.

Self-Efficacy: The confidence in the functioning of [one's] mind, in [one's] ability to think, in the processes by which [one] judge, choose[s], [and/or] decide[s]; confidence in [one's] ability to understand the facts of reality that fall within the sphere of [one's] interest and needs; cognitive self trust; [and/or] cognitive self reliance (Branden, 1992, p.16). 


\section{CHAPTER II}

\section{Review of Literature}

The purpose of this section is to provide a review of the pertinent literature related to this study. The major areas addressed are: (a) at-risk students, (b) low-performing students, (c) parental involvement, (d) academic motivation in self-efficacy, (e) reading remediation, (f) parents of low-performing students, and (g) learned helplessness. Historically, there has been no single agreed upon definition of the term at risk (Moore, 2006). The term, in part, appears in the literature to apply what the individual researcher performing a study finds suitable for their interpretation. However, the term at risk has become prevalent as a descriptor in education contexts for students who struggle academically, psycho-socially, and/or are characterized by sociological predictors (i.e., poverty, transience, identified for special education services, etc). Teachers in public education and professors in universities and colleges have identified subcultures of students in public education as being at-risk since the mid 1990's (Barr \& Parrent, 2001). At-risk Students

The U.S. Department of Education (1998) describes at-risk students as recognized by distinct differences that separate them from their same age peers with disabilities (U.S. DOE, 1994, 1998). Likewise, "at risk"" as noted by Garigulo (2008) is defined as characterized by biological and environmental conditions that increases an individual's 
chance of a life of developmental issues and that environmental and biological factors may significantly impact the child's health, employment and their personal behavior.

The issues identified in the research literature that characterize students who are at-risk are paramount in public education. Aligned with Barton (2005), literature documents issues that plague children who are labeled at-risk before they enter the home and school. Low-income children at birth are likely to have poor prenatal care, prematurity, "slow cognitive development, hyperactivity, breathing problems, [may be] overweight, and [heart disease] heart disease" (MacArthur Foundation, 2007, p. 13). Low-performing youth are often exposed to large amounts of lead in the home setting in their early stages of development. This exposure leads to "reduction in I.Q. and attention span, reading and learning disabilities and behavior problems" (CDC, 2003 \& Barton, 2003, p. 16). Documented issues report that long-term exposure into adulthood will manifest such damage as disease. Types of disease may result in hypertension, high blood pressure, weight gain and conditions that shorten the life expectancy.

The National Transition Study of Special Education (NTS, 1995) indicated that fifty-five percent of low-income minorities, who are at-risk, drop out of school. Additional information concluded that low-performing students, who drop-out, compiled a thirty-five percent arrest rate three to five years after they left school, in addition, after they left school seventy- five percent of these students were re-arrested (Hawkins, 1999). Besides their interaction with law enforcement one-third of at-risk youth are not employable three years after leaving school and are nineteen percent more likely to lose their job than same age peers (Hawkins, 1999). 
Furthermore, students who meet this label tend to have a higher propensity toward receiving poor grades than white, Asian, and other racial groups. Students who are labeled at risk according to the U.S. Department of Education (1998) are seventy-seven percent more likely to fail at least on class during high school. Students who come from an environment labeled as at-risk may have a tendency to repeat grades, especially by the tenth grade when the frustrations of academic success manifest themselves through high dropout rates (McPartland \& Slavin, 1990). An example of students' personal feelings regarding their retention as minority students found at-risk "students" ranked retention [or being "held back" a grade in school] in the same category as going blind or losing a parent to death" (Roderick, 1995, Kelly, 1999, p. 48). Consequently, students labeled atrisk have the highest level of dropout rates among all students with disabilities (Roderick, 1995).

\section{Low-Performing Students}

The chronicle of literacy failure for low-income minorities is extensive in America. Nationally, the reading skills of many low-performing students indicate that they fail to achieve at basic levels. In addition, reading failure for non-English speakers has become an even greater task for American public schools (Special Early Childhood Report, 1997) with little research dedicated to address this issue (National Reading Panel 2000; Snow \& Burns, 1998). According to the 2000 U.S. Census, nearly one person in five (or 47 million U.S. residents age 5 and older) spoke a second language other than English at home in the year 2000. The continued growth in the number of speakers of languages other than English is reflected in the rapidly increasing number of students in U.S. schools for whom English is a language. 
The National Assessment of Education (Campbell, 2001) reported that $63 \%$ of low-performing fourth grades read below basic levels as compared to $27 \%$ of the majority students. Failure to attain basic levels of reading competence contributes to lower levels of academic achievement (Craig, Thompson, Washington \& Potter, 2004). Students who come to school having being exposed, according to the National Reading Panel (2003), to strong phonemic awareness skills, "how sounds work" (p. 2), phonics instruction, "the relationship between the letters of written language and the individual sounds of spoken language" (p. 12), fluency instruction, "the ability to read a text accurately and quickly" (p. 22), vocabulary, "the words [they] must know to communicate effectively" (p. 34) and understanding text comprehension, "what they are reading" will have a strong academic foundation for later reading success (Simmons et al., 2007). Frequent readers are students who have positive beliefs about their ability to read. Children who incorporate reading daily into their diet are better readers, most importantly, they comprehend reading material more efficiently (Alger, 2007). In addition, students who increase their reading comprehension are more likely to have better motivation to read, further expanding to other content areas regarding achievement. The student's positive belief regarding reading is characteristic of their exposure to the prerequisites required for early reading (Wright, Diener \& Key, 2000).

Parents of low-performing students often do not realize that speech and language learning begin before children enter school. Having these deficiencies often deter successful academic experiences for low-income minorities in school. Such deficits continue to contribute to generational poverty, in addition, making it difficult for these students to avoid high suspension rates, retention and school discipline (Nagakoa \& 
Roderick, 2004). Retention issues often lead to low-performing students being 55\% more likely of dropping out of school by age sixteen or around the tenth grade and becoming $19 \%$ more likely to be arrested leading to incarceration (Archwamety \& Katsiyannis, 2000). When students depart school they are automatically at-risk for higher rates of suicide, violent behavior, low social expectations, and family problems as a result of their decision. Many of these dropouts will continue to have "severe deficits in basic skills, such as, reading and math" making them virtually unemployable with poor life options (Archwamety \& Katisyannis, pg. 161).

Substantial research based reading strategies are needed to reduce reading deficits (Baker, 1991), through implementation of early intention reading programs (Coleman \& Vaughn, 2001), rather than waiting until grade three and six when implementation of reading strategies are too late (Cook \& Hill, 1990).

Reading readiness requires students to be able to have social and emotional development stimulation, physical well being, cognition and general knowledge (Unrau, 2004). McNeal (1999) reported that there are several additional factors affecting the reading achievement of low-performing students: parents as caretakers, creating a culture of education through discussion about plans after high school, access to strategies to enhance their child's education; and encouraging reading.

Low-income students who are not read to by an adult frequently before entering kindergarten perform below the basic reading level by the end of first grade (Allington, 2001). This leads to low-performing students spending the rest of their academic lives being in classrooms where they are trying to remediate reading deficits and keep up with 
the pace of the reading program while falling further behind in reading development (Ford, 2006).

Knowing the outcomes of poor reading success for low-performing students, educational institutions could institute reading initiatives "to raise performance through increasing [reading] self efficacy" (Lane, Lane \& Kyprianou, 2004, pg. 248) and by "providing programming that will allow for improved performance, continuous school attendance, and graduation (Archwamety \& Katsiyannis, 2000, pg. 165).

Lundberg (1998) recommends that schools should first encourage parents to introduce reading at an early age for low-income children to increase their self-efficacy and self-confidence. Parents should create a structured environment that is print rich, full of periodical, word games and encyclopedias for the child to spend time reading, ideally with adults, older siblings or family members, to spark their interest in reading. This time created for reading should not be forced on the child, but agreed upon as a requirement for privileges and parents or caretakers should remember that the material being read should be at the child's comfort level (Epstein, 2001). Accessibility to libraries, storytelling time, and using technology will also enhance the literacy experiences of young children.

\section{Parental Involvement}

Parental involvement was noted as a primary ally in reducing the achievement gap in literacy (Thompson, 2008). Parental involvement at school includes parents and caregivers attending parent teacher conferences, attending programs featuring students, and engaging in volunteer activities (Lee \& Lee, 2002). There should ideally be a level of parental communication that is developed with teachers through, notes, phone calls, 
emails, and parent-teacher face to face visits that take place frequently during the school year (Gartland, 1993).

However, Epstein (2001) reports that four percent of low-performing parents are involved in school activities while 70 percent are completely uninvolved in activities. For low-income families, there are numerous issues that prevent parent involvement in school activities (Barr \& Parrett, 2001). One reason for this may be that many parents of low income students do not comprehend the importance of school involvement (Lee, 2002), based on their prior educational experiences or that these parents' lives are complex and they are not able to explicitly integrate school participation into their lives (Montgomery, 2005).

In her study, Boulay (2005) examined the relationship between parental involvement and the success of immigrant populations, Boulay (2005) found that "Compared to 72 percent of non-Hispanic white parents who attended school events, only 51 percent of Hispanic parents and 54 percent of non-Hispanic black parents had done so, additionally, 25 percent of Hispanic and non-Hispanic blacks volunteered their time in schools as opposed to 43 percent of non-Hispanic white parents" (Boulay, 2005, p. 17).

As one may expect, these factors were less likely found in the homes of middle-income students.

Parents of low-performing students are hesitant to participate in school activities because most are unaware or do not know what is required of them (Vondra, 1999). Most parents have work schedules that impede their ability to participate and are often reliant on notes. Parents often have contact with teachers when contacted by the school 
to discuss disciplinary actions (Leyotte, 1999). This unfortunately adds to their underrepresentation in the activities of the school. This involvement is even less in single parent homes (Barton, 2001). For low-income minorities who have language deficits and literacy issues, with an estimate of fifty percent for Hispanic populations (Guzman, 2001), participation is even less. When parents are not involved, students experience more aggression, depression and, and lower school completion (Govender \& Moodley, 2004).

\section{Academic Motivation in Self Efficacy}

A preponderance of evidence in the research literature suggests that lowperforming students have multiple deficits that prohibit opportunities to experience academic success (May \& Rizzardi, 2002). Equally important are the problems lowperforming students persistently encounter with academic motivation. Research in the last twenty years by motivational theorists in the attempt to further understand motivation and its etiology has pinpointed self-efficacy as essential when discussing motivation and low-performing students (Pintrich \& Schunk, 2002). Additionally, understanding affect and its relationship to academic achievement has been researched and identified as an important predictor of a documented lack of academic success for low-income minorities in reading achievement (Heyman, 1990). Similarly, studies have identified the significance of poor academic self-concept (Maag \& Behrens, 1989) and poor selfefficacy for academic tasks (Alderman, 2004) as predictors of poor readers.

Wigfield and Guthrie (1997) assert that having the motivation to read is essential for students to move toward independence and to consistently experience success in all facets of academic engagement. Together with reading text that is intense, purposeful 
and of interest to the reader (Unrau \& Schlackman, 2006) reading success and academic independence are positively correlated with comprehension of texts (Guthrie, Wigfield, Metsala, \& Cox, 1999). Therefore, low-performing students who have poor motivation tend to have lower academic motivation than higher achieving students; that is, they are less likely to read, which results in poorer comprehension and an increased probability of falling behind their peers (Nelson, 2005) in educational attainment.

Covington (1992) posits that low-performing students' academic motivation typically declines from elementary through high school. More specifically, Harter (1981) discovered a decline in performance beginning in grade three and continuing through high school. Research by Schunk (1991) asserts that low-performing students with poor self efficacy may put forth minimal effort and resist continuing reading which translates into other content related activities when they become frustrated. In another study by Schunk (2003) self-efficacy appears to be crucial in low minority students' development of academic achievement, cognitive engagement and the confidence in implementing strategies to gain academic success. Additionally, the attribution theory is associated with self-efficacy in that students' who continually have low academic success eventually feel guilt and shame in their ability to learn at comparable levels to proficiently performing peers. These persistent shortcomings often lead to continued reading failure (Snow, Burns \& Griffin, 1998).

The development of low academic motivation in low-performing students has been labeled a treacherous cycle (Alderman, 2004). Further, Miller and Norman assert that low-income students who consistently are victims of failure through poor academics are socialized to see themselves as not being able to have desired academic outcomes 
(Nelson, 2005). Low-performing students who are in elementary and middle school are specifically susceptible to motivational problems, as opposed to middle-income students. This trend, in turn, may contribute significantly to a lack of motivation in low-performing students to read (Craven, Marsh \& Debus, 1991). Concurrently, as students who struggle with literacy learning move into higher grades, they are more often likely to have a predisposition for decreased academic motivation (Nelson, 2005). Adolescent students are cognizant of relational or normative comparisons of themselves with peers (Boling \& Evans, 2008). For those who struggle academically, these difficulties are noted in decreases in attribution and increases in social comparison. For instance, Piaget's (1965) developmental theories introduces egocentric thinking in relation to students who, as they become mature, no longer are interested in their own interpretation of self, but of what others perceive of their abilities. Simply stated, low income, adolescent minority students are capable of comparing their own inadequacies in reading with other same age peers and become discouraged at this assessment (Ogbu, 1998). Moreover, as the importance of standardized testing becomes more visible in higher grades and competition is more prominent (Harter, Whitesell \& Kowalski, 1992) adolescent students' identification of their own deficiencies is more profound (Nelson, 2005). Thus, "The older the struggling reader, the more the struggle will be interpreted as reflecting low ability with the child unmotivated to learn to read" (Pressley, 1998, p. 233). Another significant point to include are the reading demands that begin to increase across academic content areas for upper elementary and middle school students. The emphasis on standardized testing and completion of education milestones for students created by achievement gains of schools may contribute to poor motivation of 
low-performing students. Research documents the emphasis in upper and middle grades in teachers' instruction no longer relies on learning to read, but now emphasizes reading to learn (Torgeson, 2000). The emphasis on expository and narrative text may create major issues for low-performing minority students as they enter the fourth grade. In expository texts the difficulty in understanding description, collection, causation, problem/solution and comparison make it difficult for low-performing minority students who struggle with reading longer passages "without prompts from a conversational partner, understanding arguments that are more abstract, and the wide range and complexity of text structure" (Nelson, 2005, p. 7).

Students who are fully engaged in the learning process are generally more motivated than their less motivated same age peers (Brozo \& Flynt, 2008). Children who are motivated to become highly self-efficacious are more likely to become lifelong readers, which at the elementary school age is a critical time frame to consider for teachers when they are motivating students with reading activities that incorporate the child's interest and sustains their attention (Morrow, 1992). Research showed that economically privileged or not, highly self-efficacious students outperform their less efficacious peers. Having the belief and confidence in the ability to successfully accomplish meaningful academic task, while producing a desired outcome in school, is crucial to having self-efficacy. Highly self-efficacious students tend to be more satisfied with their pre and post performance on reading inventories than lower achieving students. Additionally, "high [efficacious] students are more accurate in their prediction of the number of questions on a test that they will likely answer correctly than lower [efficacious students]" (Chen \& Zimmerman, 2007, p. 221). 
McPherson (2007) notes "children who read frequently and actively exhibit higher comprehension rates and attain higher achievement scores than children who do not read as such" (McPherson, 2007, p.71). In spite of this, children who incorporate daily reading into their diet are better readers. They comprehend reading material more efficiently; in addition, students who increase their reading comprehension have better motivation to read, thereby, further expanding this efficacy to other content areas resulting in increased achievement (Allington, 2001).

Creating a classroom environment for self-efficacy to be attained by reluctant readers is possible if teachers incorporate classroom conditions that improve selfperception and a willingness to stay motivated until a desired outcome is acquired (Pintrich \& Schunk, 2001). When the focus of the classroom is on increasing selfefficacy, "beginning readers who experience...success in learning to read can engage in reading for information, as well as, for pleasure" (Chapman \& Tunmer, 2003, p. 5).

The literacy research consistently documents that frequent readers are students who have positive beliefs about their abilities to read and function as literate beings (Beers, 2004). Students' positive beliefs regarding reading are characteristic of their exposure to numerous prerequisites required for early reading and emergent literacy (Wright, Diener \& Kay, 2000). Parents of students who exhibit good literacy skills understand the importance of incorporating speaking and reading during the early stages of development prior to coming to school. However, parents of low-performing students do not realize that speech and language learning begins before children enter school. These deficiencies often deter successful academic experiences for low-income minorities in school (Finn, 1999). These deficits, in turn, are likely to continue to 
contribute to generational poverty. As well as the previous cited factors that contribute to poor student success, readiness requires students to experience positive social and emotional development, physical well-being, an approach to curiosity, experiences that stimulate cognition and general knowledge (Ernsbarger, 2002). Preventive strategies that can deter problems with poor literacy experiences include parent and child interactions prior to entering school and home visitation programs for low-income parents to ensure proper reading strategy implementation and appreciation for literacy activities are practiced (Govender \& Moodley, 2005).

All in all, low-performing students who experience low reading motivation and poor literacy achievement frequently come to eventually believe that reading as a human activity creates frustration in their lives (McKenna, 1995). As low-income students progress through elementary school and beyond and continue to have reading failures the more decline they are likely to have in the interest of and success with reading (Unrau \& Schlackmann, 2006) in formal and informal educational settings.

\section{Reading Remediation}

Understanding the importance of literacy is a key issue in the United States, as evidenced by the recent Read First and No Child Left Behind initiatives (Bursuck, Smith, Munk, Damer, Mehlig \& Perry, 2004). The National Center for Educational Statistics (NCES) reported that " 40 percent of fourth grades read below a "basic level" and have "little or no mastery of the knowledge and skills necessary to perform work necessary at each grade level" (Bursuck, et al., p. 303). Millions of dollars are spent yearly to devise research based strategies and interventions to curtail adults and children from living a life plagued by illiteracy (Ekwall \& Shanker, 1988). Educators must focus their attention on 
high quality research based reading programs that are needed early to address reading deficiencies of low-income students. In a 1999 American Federation of Teachers report, Teaching Reading is Rocket Science: What Expert Teachers of Reading Should Know and Be Able To Do (Retrieved March 15, 2009, from http://www.aft.org/pubsreports/downloads/teacher/rocetsci.pdf), a synthesis of the struggles teachers face in teaching reading is presented with an urgent call summarized that the area of understanding the importance of reading remediation needs special attention in preservice and in-service teacher preparation programs and in districts' professional development offerings for teachers.

Pang and Saban (1998) attempted to address this issue of understanding new teacher perceptions of their ability to teach reading by surveying 100 pre-service and 75 in-service teachers taking reading courses to find out their feelings about teaching reading to low-income student populations. Results indicated pre-service teachers were not better prepared to teach reading in low SES-schools, "however, sixty-five percent of the inservice teachers felt that even a teacher with good teaching abilities [would] not be able to [increase]" (Walker-Dalhouse, 2005, p. 162) the reading gains of low-income students. When teachers are less self-efficacious about their ability to teach reading to low-income students, the reading curriculum and instruction is of less quality and these students are in a "fight for their lives" (Ladson-Billings, 2000) to make gains in reading. Therefore, low-income students need to be placed in quality reading classrooms that nurture a "cycle of hope as opposed to a cycle of failure" (Walker-Dalhouse, 2005, p. 162) and each should have access to teachers who are well prepared in reading pedagogy acknowledging the strengths, potential and value of each child in their class. Teachers 
should be aware of the academic level of the child especially in pacing the reading curriculum for the child to achieve reading success. Most importantly, should give feed back to the child to create a sense of entitlement and self-management in their growth as a reader (Gumpel \& Shlomit, 2000).

Research estimates that for low-income students who attend low-performing schools in urban environments the incidence of reading failure is astronomical. AfricanAmerican, Hispanic, limited-English speaking students, and those from impoverished homes fall behind and stay behind in far greater proportion than their white, middle-class counterparts. The rate of reading failure in these groups is 60 percent to 70 percent according to the National Assessment of Education Progress (NAEP, 1999).

Researcher's estimate that 95 percent of all children can be taught to read. It is clear that students in high-risk populations need interventions that prevent literacy achievement failure. When placed into schools with effective administrators and wellprepared and supported teachers, low-performing students who are economically disadvantaged can learn to read as well as their more advantaged same age peers. Further, students who lack the prerequisite awareness of sounds, symbols, and word meaning can overcome their initial disadvantage if teachers incorporate critical skills into lessons directly, systematically, and actively. Thus, while parents, tutors, and the community are all important in the contribution of students' reading success, classroom instruction is the critical factor in preventing reading problems and must be the primary focus for change. Ensuring effective classroom instructional practice is well within state and Department of Education policy dictates as well as those of school districts. 
Unfortunately, low-income minorities who enter school with severe reading impairments are more likely to have a diagnosis ranging from "mentally retarded, hearing impairment, or emotional disturbance, when in fact these descriptions are often neither accurate nor appropriate" (Heward, 2006, p. 313). According to Chapman and Chapman (2004) 40 to 70 percent of "families of children with language impairments have at least one other family member who has a language problem" (p.228). Lack of proper parental caretaking and lack of proper nutrition may be additional factors that add to higher than normal levels of stress for these students when learning to read. Schools who serve low income minorities with communication, speech and language impairments may be remiss in providing the appropriate strategy instruction for low-performing students. Teachers who work with low-performing students can seek the assistance of trained professionals from other academic areas to ensure that struggling students receive appropriate reading instruction. The research literature is clear, that "regardless of where the services are delivered, the most crucial variable is the quality of instruction that each child receives" (Heward, 2006, p. 95) beginning with the teacher.

The change in educational curriculum and national standards, sanctioned by professional specialty associations (i.e., NCTM, NCSS, NSTA, NCTE, CEC, etc.) opened a door with an influx of education reform tenents that may lead to more teachers understanding the importance of reading accountability standards rather than teacher misinterpretation as stated by Heward (2006): "for all students to succeed in schools, significant changes in educational policies and school practices must occur" (pg. 90). In addition, "as a [reading] proficient instructor, you open the minds and hearts of your 
learners, affirming that differences are not deficits" (Robins, Lindsey, Lindsey, \& Terrell, 2002. p. 149).

Thus, the role of the teacher in the educational process of a student is critical. The teacher's role is of vital importance as they are usually the first to note and report any rare changes in the child's academic and school behavior. Teachers along with the parent are more likely to report if a child needs testing for special education. Generally, the teacher should communicate often with the parents, not just reporting on the areas of growth for the child, but also on the achievement the child is making socially and academically in their class. The teacher should be keenly aware of the child's academic abilities and assess if the child needs modifications and adaptations to the curriculum. Teachers should be aware of the academic level of the child in pacing the curriculum for the child to achieve academic success and provide formative and summative assessment feedback to the child and his/her parents or guardians (Dennis, 2008).

The National Reading Panel (2000) posits that approximately 20 percent or 10 million children in the U.S. are failing to read by third grade. Vadasy, Jenkins and Pool (2000) agree that the demands of meeting accountability standards, overcrowded classrooms and limited time to individualize instruction to struggling readers, has led to the implementation of supplementary programs to increase reading gains. Students who are taught explicit reading instruction in phonological and decoding skills through early intervention programs and supplemental tutoring programs by highly trained tutors exhibit greater reading gains (Vadasy, Jenkins \& Pool, 2000). Those students who are failing to read by third grade are, unfortunately, placed in "special education under the category of specific learning disabilities" (Bursuck, Smith, Munk, Damer, Mehlig \& 
Perry, 2004, p. 303). Fortunately, there is an increased focus on the needs of poor readers by researchers using scientifically based reading instruction for teachers to remediate deficits in reading. These areas, according to Put Reading First (2003), of remediation include: phonemic awareness--"the understanding that sounds of spoken language work together to make words" (p. 3); phonics-- "the relationships between the letters (graphemes) of written language and the individual sounds (phonemes) of spoken language (p. 12); vocabulary--"the words we must know to communicate effectively (p. 34); and vocabulary--involves students "[understanding] what they are reading" (p. 48). Research continuously states that poor readers, who experience significant problems within these core areas by third grade, are unable to read or perform academically at their grade level.

\section{Parenting and Low-Performing Students}

Authoritative parenting is a concept commonly practiced in low-performing student homes. These practices are often characterized to create highly developed students in key areas of educational achievement (Maceoby \& Martin, 1983). These areas include respect for adults, fewer instances of being punished by the teacher, and generalizability of positive behaviors to other places other than the home. Students who are from homes where these practices are not as prevalent may be at-risk of academic, behavior, and mental health challenges that may, in turn, inhibit the child's development. Furthermore, when the home environment does follow the model of authoritative parenting practice social environments may limit these practices' overall effectiveness. Evidence of the importance of parental caretaking is key when the child leaves the home environment (Amato \& Fowler, 2002). 
Govender and Moodley (2004) assert that non-authoritative parents of children model characteristics that are detrimental to the child's overall developmental health. There is a tendency for the parent, especially the mother, to be insensitive to the child's nurturing needs, nonverbal with the child, to hold low expectations for their child and to be likely to use physical punishment for a child's inappropriate behavior. Interestingly, the socioeconomic status of these mothers often leads financial pressures, which cause increased hostilities toward the child. These behaviors, in turn, are likely to manifest as acting out behaviors of children in the classroom.

The importance of understanding the impact of poverty on student achievement is essential when researchers investigate the reason low income minorities lack equal or equitable access to education (Gonzales, Friedman, \& Mason, 1996). Isolation and lack of economic resources may create uneven access of children and adolescents to adequate schools and public services (Hanson, 1997). Low-performing parents are often misunderstood regarding their feelings, including advocacy or apathy, regarding the importance of their children receiving a quality education. Many low-income parents are less likely to have the time, resources, cultural capital, or social networks to spend with their children individually to enhance reading support for their children's schooling experiences (Jarrett, 1997). As well, the research literature documents that teacher's are often blamed for the misinterpretation of a student's behavior as being inappropriate solely based on cultural misconceptions (Ladson-Billings, 2004). Delpit (2003) asserts that there may be no better example of such misinterpretations more than in the area of speech and language. 


\section{Learned Helplessness}

When low-performing students experience literacy failure over the course of their educational lives they develop what is known as learned helplessness (Seligman, 1975). Pintrich and Schunk (2003) define learned helplessness as: "a pattern of learned cognitive, attributions and behaviors that lead an individual to see no contingency between the behavior and the outcomes leading to hopelessness, depression, and passivity" (p. 405). Firmin, Hwang, Copella and Clark (2000) agree that "learned helplessness is more likely to result from situation where failure is uncontrollable" (p.688). Learned helplessness is composed of three primary variables: contingency, which is the inability to have a situation under control, cognition, the way an individual perceives their fate, and behavior, which allows a person to stop or continue with a task (Firmin, et al. 2000). Learned helplessness does not discriminate against any person allowing the phenomenon to be greater in its emergence in some individuals than others. Person's who experience learned helplessness often experience failure continuously regardless of their effort. Through continual experience of failure, these individuals are often quick to quit tasks they perceive to be beyond their ability or control. Ross and Broh (2000) indicate that continued failure at a variety of task negatively impacts one's sense and actions related to personal control. This is extensively documented in research on low literacy achievement for low-income students.

These students' persistent experience with reading failure negatively influences them to identify any effort exerted toward literacy as unable to produce their desired outcome. Consequently, parents of student, who disproportionately experience reading failure, are likely to have the same feeling of self-control as the children (Ross \& Broh, 
2000). These parents are often unable to develop variables correlated with self-control such as "self reliance, personal responsibility and personal development" (Ross \& Broh, p. 272). Thus, overtime they are less likely to attempt any activities requiring problem solving and may then result to the development of reactive tendencies and passive orientation as coping mechanisms. Students who struggle academically, in turn, are documented in the research literature as having a higher tendency to drop out of school, be "at risk" of teen pregnancy, and earn less in overall salary for the rest of their lives (Dunifon \& Duncan, 1998). Students who continue to exhibit the affects of literacy failure consistently result in negative self-images of becoming "at risk" (Valas, 2001,p. 101). These negative self-images lead to students with reading disabilities (RD) "having lower self esteem than their non RD peers" (Bruininks, 1978; Kristner \& Osbourn, 1987; and La Greca \& Stone, 1990). Failure in reading also typically translates into failure in the child to experience success in other content areas (Lazarus \& Callahan, 2000), specifically mathematics, (Valas, 2001, p. 103). Furthermore, "the duration of placement in $[R D]$ classes appears to affect ...... self esteem" in a negative way (Valas, 2001, p. 102). At the same time, occurrence of internalizing behaviors in RD students, often also demonstrated higher incidence of depression than do their non-RD peers (Maag \& Behrens, 1989). Zambo and Brem (2004) assert that students who have a history of poor academic performance contribute failure to their low achievement levels or perceived abilities. In the same way, "students [who are RD] typically have low expectations of future success and high expectations of future failure in the core subjects compared with non [RD] students (Valas, 2001, p.103). Teachers who become a barrier to low-performing students' literacy success by reinforcing that the child cannot read, 
drive the child to believe that he/she is incapable of achievement in reading (Banks, 2005). Milich et al. (1992) note that

"students with [RD] may have a stigmatizing effect that in turn may create unfavorable teacher peer expectancies towards the student and the teachers assessment of the students [learned] helplessness behavior may be influenced by such expectancies." (p.19)

This phenomenon can be especially devastating since the earlier children experience poor reading success, the greater their inability to believe they are capable of performing successfully in other academic areas. Furthermore, repeated failures can lead to deeply entrenched hopelessness and helplessness for low-performing students. When low-performing students perceive that they have no control and become discouraged they become "at risk" for dropping out of school (Kozol, 2005) and for inhibited long-term opportunities. Research studies have been able to provide answers to the characteristics that make a good reading teacher. The importance of answering this question with research is critical in maximizing reading comprehension for low-performing readers (Spencer \& Boon, 2006). Research studies conducted described good reading teachers as "having a good sense of humor and good relationships with students" (Spencer \& Boon, 2006, p. 245), being passionate about teaching students' to become good readers, modeling their passion for reading to their students, and establishing communication with parents/guardians to create healthy reading experiences in the home environment.

For the occurrence of learned helplessness to decrease factors have to be addressed to meet the needs of the RD population. For instance, Martin, Martin, and Carvalho (2008) posit that direct instruction and whole language reading programs are 
best suited in classrooms with non RD peers; this is known as a balanced approach to literacy instruction (IRA, 2009). Swanson (2001) suggests that instructional time and specialization of instruction, including research-based literacy intervention programs, are essential to delay RD. In addition, the early identification of student who are $\mathrm{RD}$, coupled with remediation in the elementary school years, are key preventatives to students' behavior manifestations resulting from learned helplessness.

Equally important, is discouraging the transference of learned helplessness into the outside lives of RD students. Brendtro, Ness and Mitchell (2001) assert that this is especially true for children "with self centered and antisocial lifestyles." Put another way, as students decrease their learned helplessness "they become a valuable resource [in the school and home] instead of a liability (Brendtro, Ness \& Mitchell, 2001).

\section{Student Achievement}

Students "at risk" tend to have less access to stringent academic curriculum that prepares students for life beyond high school (Slavin, 2005). These students often attend schools where teachers are not are not as highly qualified or well prepared and may be less likely to have proper credentials to teach in low-performing schools (Kozol, 2005). Current research provides evidence of a widening of the literacy gap that continues to lengthen during primary grades (Lee, 2002). The widening a documented literacy gap creates public and policy makers' skepticism regarding the effectiveness of typical reading remediation $(\mathrm{RD})$.

Equally important, reading specialists and other researchers indicate that students who participate in learning disabilities programs and who receive reading remediation or intervention programs, are often "at risk" of suicide related occurrences (Heath, 1996). 
Studies showed a higher rate of suicidal thoughts among students with reading disabilities (RD) who are in reading programs in educational settings than for those same age peers in clinical settings who did not receive reading remediation (Newcomer, 1995). Students who experience reading difficulties $(\mathrm{RD})$ were also least likely to complete second and post secondary education (Henry, 2000). Furthermore, high absenteeism, poor homework completion, and frustration with school performance (i.e., Grades) have all been associated as factors consistent with the probability of suicide attempts (Lewinshohn, Rohde, \& Seeley, 1993).

Baumeister's research on the negative effects of students who experienced reading difficulties (1990) proposed six critical areas as causal reasons for potential suicidal attempts students with learning disabilities who were participating in reading remediation programs. The first stage proposed that students would have a negative performance related to their perceived ability. Secondly, students would blame their failure on their own innate ability and therefore have a poor self-perception. Next, students would compare their poor self-assessment to other students. Equally important, these emotions are created by the negative jargon used to explain their performance to other same age peers. Together with the students' attempts to use escape behaviors and their poor self-perceptions, these behaviors often lead to disruptive internal behaviors (Baumeister, 1990). Finally, students lose their intrinsic and extrinsic motivation that may for some, leave suicide as their perceived only viable option.

The current study was conducted to help teachers address the importance of selfefficacy of at-risk students who may also have poor reading motivation. Historically, because of socioeconomic factors, at-risk students have a past that has not allowed access 
to proper reading material, strategies, and instruction. Most compelling about the lack of access to these options, are the factors that leave at-risk students with very few choices that do not extend beyond a life engaged in criminal delinquency, high levels of participation in sexual initiation during teen years, and learned helplessness created by the lack of dependence on their basic skills needed for literacy. However, prevention programs that are research based can allow for low-performing at-risk students to pair with highly skilled teachers who are motivated to teach at-risk students reading skills by using reading remediation programs. Students can begin to acquire speech and language skills that improve their self-efficacy toward literacy. Additionally, if teacher preparation programs implement higher standards for new teachers to learn proper literacy instruction, "the two million new teachers projected over the next decade may be equipped to minimize reading failure in all but a small percentage of students" (American Federation of Teachers, 2009, pg. 8). The research questions sought to answer whether reading gains were caused by participation in reading remediation programs, and the factors that contributed to reading improvement of both programs.

Based on a review of the literature, more research is needed to address the issue of low-performing readers' self-perception of their reading abilities. The adoption of accountability assessments has led to the critique and evaluation of programs used to improve student performance; in the present study, student perceptions of their selfefficacy will be assessed. 


\title{
CHAPTER III
}

\author{
Methodology
}

\section{Introduction}

The purpose of this chapter is to describe the methods that were used in this study. The major areas addressed include: (a) survey description, (b) sample, (c) research procedures, and (d) data analysis procedures.

Since 2002, there has been an effort in Jefferson County Publics Schools in Louisville, Kentucky, to explore ideas for improving public education. The Greater Louisville Incorporated leadership concluded that in order for the city of Louisville to continue its growth and to be competitive with other major urban metropolitan cities Louisville needs to improve the education of its future workforce (JCPS, 2003). The Greater Louisville Report on Education (2003) reports that Jefferson County Public Schools is the $29^{\text {th }}$ largest school district...in the U.S. (p. 4). Although there has been a decrease in dropout rates and a number of schools being rated among the top tier schools in the state, the report indicates there are important issues that exist regarding academic performance, more specifically in the area of literacy. Of the 96,500 students who attend Jefferson County Public schools, 17,667 students are not reading at grade level (GLI Report, 2003). 
The current study examined the relationship between student reading self-efficacy and remedial reading instruction on student reading achievement at the individual student reading level. The current record of student reading achievement was taken from individual reading inventories (IRI) administered prior to placement in a remedial reading program. Furthermore, current students provided a chance to compare the relationship of student reading characteristics and their attitude regarding reading at the middle school level.

Additionally, the study addressed the degree to which self-efficacy predicted individual student reading success in a remedial reading program. Students who participated were individuals educated in the Jefferson County Public Schools (JCPS). The total number of subjects used for this study consisted of 216 students in grades six $(n=118)$, seventh $(n=54)$ and eight $(n=44)$. The sample numbers of participants, 152 of 216 , were mailed consent forms yielding a participatory rate of 70 percent, obtained from five middle schools participating in two reading intervention programs: Read 180 and Corrective Reading. Students were asked to participate in this study by parental consent forms detailing the purpose of the study. Attached to the parent consent form was the student assent form asking the parent and student for their signatures confirming their permission to participate.

This study addressed the relationship of Physiological States, Observational Comparison, Progress, and Self-Feedback as compared to other students in reading achievement. In this study the other subjects were the individual students currently participating in two remedial reading programs used in the Jefferson County Public Schools. 
Sources of Data

The Reading Self Perception Scale (RSPS) created by Henk and Melnick (1992)

provided the data for this study. The design used was a Two-Group experimental design.

Standard descriptive statistics were used to provide data on the self-perception of student reading. Read 180 and Corrective Reading assessment inventories, two-tail dependent sample t-test and a multiple regression analysis were performed for "evaluating the effects of more than one independent variable on a dependent variable" (Vogt, 1999, p.183).

Table 3.1

Matrix for Collection of Data for each Research Question.

\begin{tabular}{|l|l|l|l|l|}
\hline Research & $\begin{array}{l}\text { RQ1: Is there a } \\
\text { difference } \\
\text { between Read } \\
\text { 180 and } \\
\text { Corrective } \\
\text { Reading on the } \\
\text { reading } \\
\text { improvement of } \\
\text { Individual } \\
\text { Reading } \\
\text { Inventory }\end{array}$ & $\begin{array}{l}\text { RQ2: What are the } \\
\text { factors that predict } \\
\text { reading } \\
\text { improvement? }\end{array}$ & $\begin{array}{l}\text { RQ3: What are the } \\
\text { factors that predict } \\
\text { reading } \\
\text { improvement using } \\
\text { Read 180? }\end{array}$ & $\begin{array}{l}\text { RQ4: What are the } \\
\text { factors that predict } \\
\text { reading } \\
\text { improvement using } \\
\text { Corrective } \\
\text { Reading? }\end{array}$ \\
\hline $\begin{array}{l}\text { Data } \\
\text { Source }\end{array}$ & $\begin{array}{l}\text { Archival: Date } \\
\text { of birth/gender, } \\
\text { race, ethnicity, } \\
\text { and retention of } \\
\text { students/reading } \\
\text { level/IRI pre } \\
\text { and posttest } \\
\text { data, IEP. }\end{array}$ & $\begin{array}{l}\text { Reading Self } \\
\text { Perception } \\
\text { Scale/Demographic } \\
\text { information. }\end{array}$ & $\begin{array}{l}\text { Reading Self } \\
\text { Perception } \\
\text { Scale/Demographic } \\
\text { information. }\end{array}$ & $\begin{array}{l}\text { Reading Self } \\
\text { Perception } \\
\text { Scale/Demographic } \\
\text { information. }\end{array}$ \\
\hline $\begin{array}{l}\text { Data } \\
\text { Analysis }\end{array}$ & $\begin{array}{l}\text { Administering a a } \\
\text { t-test to } \\
\text { determine } \\
\text { differences in } \\
\text { reading } \\
\text { improvement }\end{array}$ & $\begin{array}{l}\text { Multiple regression } \\
\text { analysis will be } \\
\text { used to find the } \\
\text { overall predictive } \\
\text { factors for reading }\end{array}$ & $\begin{array}{l}\text { Multiple regression } \\
\text { analysis will be } \\
\text { used to find the } \\
\text { predictive factors } \\
\text { for Reads 180. }\end{array}$ & $\begin{array}{l}\text { Multiple regression } \\
\text { analysis will be } \\
\text { used to find the } \\
\text { predictive factors } \\
\text { for Corrective }\end{array}$ \\
\hline
\end{tabular}




\begin{tabular}{|l|l|l|l|l|}
\hline & scores. & improvement. & & Reading. \\
\hline
\end{tabular}

\section{Participants}

The participants were chosen based on low scores on the individualized reading inventory administered during the first month of their sixth grade year of school. This selection parameter was based upon the end of the school year assessment data gathered by IRI's administered prior to the summer break for students in grade seventh and eighth grade. The remedial reading population consisted of 216 middle school students in an urban school district that was currently implementing two remedial reading programs: Reads 180, and Corrective Reading. The ages of the student participants were 12-14 years old. The rate of participation was 70 percent along with, producing a sample size of 152, (Krejcie \& Morgan, 1970). The Institutional Review Board (IRB) of the University of Louisville approved student consent forms. Permission to conduct research in the school district was secured from the Internal Review Boards of the University of Louisville and of the Jefferson County Public Schools. This approval process included oversight of procedures, consent forms and all appropriate research protocol including protection of human subject rights. It was clearly noted and explained on the consent forms that taking part in the study is voluntary. In addition, contact information was provided to parents by the researcher if questions arose about the research study or concerns about their rights as parents.

\section{Schools}

Jefferson County Public School district has twenty-four middle schools of which numerous awards have been designated from the No Child Left Behind Blue Ribbon 
School by the United States Department of Education (USDOE). Two schools were designated as 2007 Schools to Watch by the Nation Forum to Accelerate Middle School Grades Reform and accreditation as a Quality School District by the Southern Association of Colleges and Schools. Five schools were randomly selected based on their use of the two remedial reading programs. Additionally, schools considered Alternative schools for troubled students were also included in the random sample of schools for this study.

\section{Ethnicity}

"Although some socio-economic, racial, and family structure diversity [was] evident in the sample, the majority of the respondents" (Coleman, Karraker, 2000, p. 15) represented various ethnic backgrounds.

Gender

Male and Female middle school students were included in study. Students were first selected based upon their IRI scores. There were 85 female and 135 males in the Read 180 group and 85 females and 138 males in Corrective Reading group.

\section{Socioeconomic Status}

Schools that participated in the study received Title I funding. This indicated that at least fifty percent of the students were from low socioeconomic backgrounds. This receipt of federal funding by school districts is used to create researched-based reading programs mandated by the federal government to improve reading achievement in schools (NCLB, 2001). 


\section{Disability}

Schools in urban school districts are likely to have a large population of students who receive special education services. Services and modifications during administration of the RSPS, as indicated by their individualized education program (IEP), were granted to all students receiving special education services (i.e., more time, scriber or a peer tutor, etc.). Thirty-one percent of the students received special education services for the Corrective Reading and sixty-nine percent of students received special education services for Read 180 group.

\section{Instrumentation}

The Reading Self Perception Scale (RSPS) took 45-60 minutes to administer. The teacher allowed for more time according to the needs of specific learners. The Reading Self Perception Scale (RSPS) originated from a research study that investigated how adolescents felt about themselves as readers (Henk \& Melnick, 1995). The scale included 33 items that assessed self-perceptions regarding four dimensions of selfefficacy (Progress, Observational Comparison, Social Feedback, and Physiological States). Students were asked to describe their feelings about each item on a 5-point likert scale $(5=$ Strongly Agree, $4=$ Agree, $3=$ Undecided, $2=$ Disagree, $1=$ Strongly

Disagree). This information was used to examine better reading strategies to improve the child's self-esteem in literacy and to increase their motivation. The scoring was performed by adding the raw score of each of the four individual categories of Progress (45), Observational Comparison (30), Social Feedback (45) and Physiological States (40) (see Table 3.4). 
Table 3.2

The Reader Self-Perception Scale Descriptions. (RSPS: Progress, Observational Comparison, Social Feedback, Physiological States)

Progress

"how one's perception of present reading performance compares with past performance."

Obsv. Comparison "deals with how a child perceives his or her reading performance to compare with the performance of classmates"

Social Feedback "includes direct or indirect input about reading from teachers, classmates, and people in the child's family."

Physiological States "refers to internal feelings that the child experiences during reading

Note. Henk \& Melnick, 1995, p. 472

Individual student scores was calculated by comparing the raw score to the norm score for that category. Scores that were "equal or slightly greater than the mean" (Henk \& Melnick, 1995, p. 474) denoted the students self-perception is rated as normal. Student scores that were significantly below the mean for the scale category were to be addressed by the teachers.

Procedure

A cover letter was sent home with the students in grades six through eight during the fall of 2008, requesting parent consent and student to participate in the study. Yellow colored paper was used to alert students as to the importance of having the form signed by their parents, a recommendation provided by the school administrators. Contact information was provided to parents by the researcher if questions arose about the 
research study or concerns about their rights as parents were voiced. The researcher made additional follow up phone calls and emailed administrators every fifth day to check on the progress of the forms being returned to school by the students. After fourteen days, the researcher returned to each school to pick up the forms returned by the students.

Table 3.3

Research Project and Task Timelines

Seek Research Topic Approval

April 2008

Seek Site Sponsor Approval

September 2008

Seek Institutional Review Board Approval September 2008

Initial Defense of Research Proposal

April 2008

Plan/Collect Data

August 2008-March 2009

Complete Statistical Analysis

March 2009

Ongoing Writing and Revisions

June 2007-March 2009

Final Defense

April 2009

Complete Final Revisions

April 2009

Submit to University

April 2009

This study investigated and described student participants in two remedial reading programs for low income and forty non-minority students in a southern urban school district. This study used a self-efficacy design instrument and reading test material intended to measure the reading skills of low income and minority students enrolled in the remedial reading programs. To study self-efficacy, the researcher administered a self-efficacy assessment to gather information regarding student attitudes toward reading. 
Equally important, is knowing that both programs dealt with reading comprehension strategy instruction, but each of the two remedial reading programs differed in teaching explicit reading strategies (Nelson, Williamson, 2006, pg. 216).

Read 180

Low-income students between grades four through twelfth grade in the United States have difficulty reading at grade level. These students who experience serious reading difficulty will have problems participating in the socioeconomic world in which they live. Reading intervention is an integral part in helping students to acquire reading skills to succeed in schools and their daily lives.

Read 180 addresses the key gaps in student literacy skills to help students reach reading proficiency. Along with, technology, direct instruction, and individual reading components used in Read 180, low-income and minority students are now able to acquire research based reading strategies that can change their attitudes about school and reading. Students participating in the Read 180 program were found to have positive, statistically significant improvement in reading. Furthermore, the dropout rates of low income and minority students were decreased (Scholastic, 2006). Corrective Reading

Corrective Reading is a direct instruction remediation program, which teaches students basic reading skills that extend toward more complex strategies and skills development. The program is scripted and fast in pace with carefully chosen reading exercises, sample items, and presentations to engage reluctant readers. All materials for remediation were provided from student workbooks and other additional material (Martella, Martella \& Havis, 2000). 
The survey scale that was used in this study was obtained from a previous research study, which examined factors that influence reader self-efficacy (Henk \& Melnick, 1995). Table 3.4 provides a description of the Reader Self Perception Scale's four factors. The Reader Self Perception Scale consisted of 1 general item question and 32 questions that were measured on four scales: Progress (9) alpha reliability of. 84; Observational Comparison (6) alpha reliability of .82; Social Feedback (9) alpha reliability of .81; Physiological States (8) alpha reliability of .84 .

The participants had five responses to choose from in the Likert scale format. The choices were strongly agree (SA); agree (A); undecided (U); disagree (D); and strongly disagree (SD). For analysis, each item was scored using a point value associated with a statement see Table 3.4.

Table 3.4

Point value for the Reading Self Perception Scale scoring key

\begin{tabular}{llc} 
Point Value & \multicolumn{1}{c}{ Statement } & Abbreviation \\
\hline 5 & Strongly Agree & (SA) \\
4 & Agree & (A) \\
3 & Undecided & (U) \\
2 & Disagree & (D) \\
1 & Strongly Disagree & (SD) \\
\hline
\end{tabular}


The importance of understanding the self-efficacy of low-performing readers was essential to this study; therefore, the following research questions were examined using inferential statistical analysis:

Research Questions

Using the RSPS instrument and the respective Progress, Observational Comparison, Social Feedback and Physiological States scores for each sample, See Table 3.1 for methods used for collecting data:

1. Is there a difference between Read 180 and Corrective Reading on the reading improvement of Individual Reading Inventory?

2. What are the factors that predict reading improvement?

3. What are the factors that predict reading improvement using Read 180 ?

4. What are the factors that predict reading improvement using Corrective Reading? 


\section{CHAPTER IV}

\section{Results}

\section{Introduction}

The purpose of this chapter is to report the results of this research. The sample and demographic information are first presented. Next, each research question is posed, followed by data analysis. This study was designed to examine the relationship between self-efficacy and reading success of students in two remedial middle school reading programs. Further, the researcher examined two reading programs used by the Jefferson Country Public School system and predictive factors for reading improvement.

In this study $68 \%$ of the Read 180 group $(\mathrm{n}=153)$ and $32 \%$ of the Corrective Reading group $(\mathrm{n}=70)$ students were receiving special education services (ECE).

Participants were 214 (male $n=138$; female $n=85$ ) middle school students. Six grade students constituted $61.8 \%(\mathrm{n}=118)$ of the sample, while seventh grade students made up $25 \%(n=54)$ of the sample, and eighth grade students made up $20 \%(n=44)$ of the sample. Approximately, $55 \%$ of the sample identified themselves as Black $(n=126)$, $32 \%(\mathrm{n}=73)$ as White, $0.02 \%(\mathrm{n}=8)$ as Hispanic, $0.004 \%(\mathrm{n}=6)$ as Asian, $0.0046 \%(\mathrm{n}$ $=1)$ as Indian and $0.042 \%(n=9)$ did not report ethnicity. The statistical analysis for the study was computed using SPSS: Windows: Advanced Graduate Package (Version 16.0). 
Analysis

Data were collected using the Reader Self Perception Scale (RSPS) and other demographic information (i.e. grade, gender, race, ECE, and IRI), which provided information by measuring the four factors associated with self-efficacy: Progress $(\mathrm{m}=34.9)$, Observational Comparison $(\mathrm{m}=19.5)$, Social Feedback $(\mathrm{m}=32.8)$, and Physiological States $(\mathrm{m}=26.4)$. A Two-sample t-test was used to examine whether Read 180 and/or Corrective Reading intervention increased the gains on the dependent variable. The reason for using the t-test was to "decide whether the sample mean was drawn from a hypothesized population with a specified mean or whether it was drawn from some other different mean" (Shavelson, 1996, p. 334). A step wise multiple regression analysis was used to identify significant (at the .05 level of significance) independent variables as predictive factors for the dependent variable reading percentage $(\%)$ improvement. Multiple regression analyses were used for "evaluating the effects of more than one independent variable on a dependent variable" (Vogt, 1999, p. 183).

\section{Results of the Current Study}

\section{Preliminary Analyses}

The Reading Self Perception Scale (RSPS) was used to gather information about the students reading self-efficacy. A visual inspection of the score interpretations for the RSPS in Table 4.1 indicated that students who participated in the two reading interventions scored in the low range on the RSPS in all categories, except for Social Feedback, which yielded an average score of 32.8 . See Table 4.2 for score interpretations of the RSPS for self-efficacy. Table 4.3 provides reliability data for Progress, Observational Comparison, Social Feedback, and Physiological States for the RSPS. 
Table 4.1

Average Mean Score for the Four Factors Associated With Reading Self-Efficacy. (RSPS: Progress, Observational Comparison, Social Feedback, Physiological States)

$\underline{\text { Variable }}$

$\underline{\mathrm{N}}$

Mean

Std. Dev.

Progress

152

34.9

7.3

Obs Comp.

152

19.5

4.7

Social Feedback

152

32.8

23.8

Phys States

152

26.4

7.8

Table 4.2

Score Interpretation of the Reader Self-Perception Scale (RSPS: Progress, Observational Comparison, Social Feedback, and Physiological States)

$\underline{\text { Score Interpretations } \quad \text { Progress }}$ Obs. Comp. $\underline{\text { Soc. Feedback }}$ Phys. States

$\begin{array}{lllll}\text { High } & 44+ & 26+ & 38+ & 37+ \\ \text { Average } & 39+ & 21+ & 33+ & 31+ \\ \text { Low } & 34+ & 16+ & 27+ & 25+\end{array}$

Table 4.3

Reliabilities for each scale (RSPS: Progress, Observational Comparison, Social Feedback, Physiological States)

Scale

No. of Items

Alpha reliabilities 
Progress 9

Observational Comparison $\quad 6$

.82

Social Feedback

9

.81

Physiological States

8

.84

Note: The RSPS consist of 33 items with 32 items representing the four scales show here plus 1 general item ("I think I am a good reader"). $\mathrm{n}=152$

\section{Analysis for Research Question 1}

Is there a difference between Read 180 and Corrective Reading on the reading improvement of Individual Reading Inventory (IRI)?

The hypothesis by the researcher sought to determine whether Read $180(\mathrm{n}=153)$ results would be different from Corrective Reading $(n=70)$ results for low-performing readers on the IRI, see Table 4.4. A two-tail dependent sample t-test for means was conducted to determine if Read 180 was different than Corrective Reading. The two-tail dependent sample t-test administered on the reading gain mean scores of the reading groups did not yield a significant $p$ value. A significant difference was not discovered between the Read 180 students' data and the Corrective Reading students' data based on their gain scores on the (IRI): $\mathrm{t}=.891, \mathrm{df}=156, \mathrm{p}=.374>.05$. A $\mathrm{p}$-value of .374 was used instead of .229, since Levene's test for equality of variances indicated that equal variances could be assumed. The data analysis did not support the hypothesis that there is a statistically significant difference between the Read 180 and Corrective Reading. However, at .05 level of significance, Corrective Reading has a significantly higher improvement $(-59.7339)$ than Read $180(-15.9157)$, since $\mathrm{p}=.027$ (half of .054$)<.05$. 
See Table 4.4 for descriptive statistical information for the pre-test and post-test data of the two groups. Table 4.4 also provides descriptive information about the mean, standard deviation and standard error of Read 180 and Corrective Reading.

Table 4.4

Dependent sample statistic for Read 180 and Corrective Reading

Group $\mathrm{N}$ Mean Standard Deviation Standard Error Mean

Read $180 \quad 55$ $-15.9157$

42.48802

5.72908

Corr. Read 103 $-59.7338$

362.844459

35.75214

Secondly, to find the differences within each reading program, the researcher sought to determine whether Corrective Reading $(\mathrm{n}=56) 2008$ IRI results would be different than Corrective Reading 2009 IRI results for low-performing readers (see Table 4.5). A two-tail dependent sample t-test was conducted to determine if Corrective Reading results were different on the IRI. The two-tail t-test administered on the reading gain mean scores of the 2008 and 2009 reading scores yielded a significant $t$ value. A significant difference was discovered between the Corrective Reading students 2008 data and the Corrective Reading 2009 students' data based on their gain scores on the (IRI): $\mathrm{t}=2.965, \mathrm{df}=55, \mathrm{p}$-value $.004<.05$. There was at .05 statistically significant difference between Corrective Reading 2009 IRI reading scores (538.23) and Corrective Reading 2008 IRI reading scores $(627.64)$ see table 4.5. 
Table 4.5

Dependent Samples Statistics for Corrective Reading

\begin{tabular}{lrrcc} 
Group & N & Mean & Standard Deviation & Standard Error Mean \\
\hline IRI 2008 & 56 & 627.64 & 271.20937 & 36.24188 \\
IRI 2009 & 56 & 538.23 & 204.05151 & 27.26753
\end{tabular}

Third, to find differences within each reading program, the researcher sought to determine whether Read $180(\mathrm{n}=106) 2008$ IRI results would be different from Read 1802009 IRI results for low-performing readers. A two-tail dependent samples t-test for means was conducted to determine if Read 180 results were different on the IRI, see Table 4.6. The two-tail dependent samples t-test administered on the reading gain mean scores of the 2008 and 2009 reading scores did not yield a significant $t=.636, \mathrm{df}=105$, $\mathrm{p}=.526>.05$. For Read 180 , there is no statistically significant difference between the two mean IRI 2008-2009 scores for Read 180. There was no statistically significantly difference in IRI scores at the beginning and the end of the program. See table 4.6 for descriptive statistical information for the pretest and posttest data of the two means, Table 4.6 also provides descriptive information about the mean, standard deviation and standard error of the mean for Read 180 . 
Table 4.6

Dependent samples Statistics for Read 180

\begin{tabular}{lcccc} 
Pair 1 & Mean & $\mathrm{N}$ & Standard Deviation & Standard Error Mean \\
\hline IRI 2008 & 508.58 & 106 & 189.25246 & 18.38182 \\
IRI 2009 & 497.17 & 106 & 215.56737 & 20.93775 \\
& \multicolumn{4}{r}{ Analysis for Research Question 2 }
\end{tabular}

What are the factors that predict reading percentage improvement for Corrective Reading and Read 180 ?

Using the Reading Self Perception Scale (RSPS) (see Appendix A) and other demographic information, a stepwise multiple regression analysis was used to identify significant (at the .05 level of significance) independent variable predictive factors for the dependent variable, reading percentage improvement. There were 13 independent variables (see Table 4.7).

The significant regression prediction equation developed from this process was percentage improvement $=2.715-144.006($ School D). Based upon the standardized residuals for this equation, using an appropriate histogram, norm plot, and scatter plot, the usual assumptions of normality, constant variance, and linearity appeared to be satisfied for this model.

The coefficient of determination, R squared, for this regression equation was .053 . However, the adjusted R squared was .046. This indicated that approximately $4.6 \%$ of 
reading improvement is predicted by School D and $95.4 \%$ of the variability would need to be explained from other factors.

The Pearson correlation matrix involving the independent and dependent variables indicated that several of the independent variables were mild to moderately significantly $(p<.05)$ correlated with the dependent variable, Percentage Improvement. Independent variable predictors were sometimes significantly correlated with one another. For example, the variables School $\mathrm{C}$ and Progress were significantly correlated, $\mathrm{r}=.224, \mathrm{p}=.003$. In addition, School D and Observational Comparison were significantly correlated, $\mathrm{r}=-.158, \mathrm{p}=.05$, as well, Race and ECE were significantly correlated, $r=-.164, p=.042$, see Appendix $C$ for percentage reading improvement correlation table.

\section{Analysis for Research Question 3}

What are the factors that predict reading improvement using Read 180?

Using the Reading Self Perception Scale (RSPS) (see Appendix A) and other demographic information, a stepwise multiple regression analysis was used to identify significant (at the .05 level of significance) independent variable predictive factors for the dependent variable, reading percentage improvement for Read $180(\mathrm{n}=99)$. There were 13 independent variables (see Table 4.7).

The significant regression prediction equation developed from this process was Percentage Improvement $=2.491-201.296($ School D). Based upon the standardized residuals for this equation, using an appropriate histogram, norm plot, and scatter plot, the usual assumptions of normality, constant variance, and linearity appeared to be satisfied for this model. 
The coefficient of determination, $\mathrm{R}$ square, for this regression equation was .065. However, the adjusted R squared was .056 . This indicated that approximately $5.6 \%$ of reading improvement is predicted by School D and $94.4 \%$ of the variability would need to be explained from other factors.

The Pearson correlation matrix involving the independent and dependent variables indicated that several of the independent variables were significantly $(p<.05)$ correlated with the dependent variable, percentage of improvement. Independent variable predictors were mild to moderately significantly correlated with one another. For example, the variables School $\mathrm{C}$ and Progress were significantly correlated, $\mathrm{r}=.249, \mathrm{p}=$ .006. In addition, Race and Progress were significantly correlated, $r=.293, p=.002$; as well, School C and Progress were significantly correlated, $r=.249, p=.006$ (see Appendix D correlation table for Read180).

Analysis for Research Question 4

What are the factors that predict reading percentage improvement for Corrective Reading?

Using the Reading Self Perception Scale (RSPS) (see Appendices A, B, C, and D) and other demographic information, a stepwise multiple regression analysis was used to identify significant (at the .05 level of significance) independent variable predictive factors for the dependent variable, reading percentage improvement for Corrective Reading $(\mathrm{n}=55)$. There were 13 independent variables (see Table 4.7).

Of these two, School D and Gender were found to be significant predictors of Corrective Reading. The significant regression prediction equation developed from this process was percentage improvement $=-5.291-52.412($ School $D)+21.086($ Gender $)$. 
Based upon the standardized residuals for this equation, using an appropriate histogram, norm plot, and scatter plot, the usual assumptions of normality, constant variance, and linearity appeared to be satisfied for this model.

The coefficient of determination, $\mathrm{R}$ square, for this regression equation was .359 . However, the adjusted R square was .347 . This indicated that approximately $34.7 \%$ of reading improvement is predicted by School D and Gender while $65.3 \%$ of the variability would need to be explained from other factors.

The Pearson correlation matrix involving the independent and dependent variables indicated that several of the independent variables were mild to moderately significantly $(\mathrm{p}<.05)$ correlated with the dependent variable, percentage of improvement. Independent variable predictors were mild to moderately significantly correlated with one another. For example, the variables Physiological States and Progress were significantly correlated, $\mathrm{r}=.505, \mathrm{p}=.000$. In addition, School A and Social Feedback, $\mathrm{r}=.320, \mathrm{p}=.009$, and School $\mathrm{D}$ and ECE were significantly correlated, $\mathrm{r}=-.356, \mathrm{p}=.004$, (see Appendix E correlation table for Corrective Reading). 
Table 4.7

Thirteen Predictor Variables for Reading Improvement

1. School A

2. School B

3. School C

4. School D

5. School E

6. Grade

7. Gender

8. Race

9. Progress

10. Observation Comparison

11. Self Feedback

12. Physiological States

13. Early Childhood Education

Note. School E did not report 


\section{CHAPTER V}

Discussion

This chapter first provides an overview of the purpose and procedures used in this investigation. A discussion of the results by each research question is then provided in this chapter. Limitations of the investigation are presented, followed by implications. The chapter concludes with recommendations for additions.

In the current study, the relationship of Read 180 IRI and Corrective Reading IRI for self-efficacy of students in four middle schools was examined. This study sought to answer if participation in the reading programs would allow positive change in participants' self efficacy as a result of the two reading interventions and whether there were certain factors that are more common among low income readers as a result of their participation in Read 180 and Corrective Reading.

Were there differences in improvement by participating in the Read 180 and Corrective Reading interventions? Overall, there were no statistically significant differences in improvement for Read 180 and Corrective Reading using the two-sample ttest. However, there was a .05 statistically significant difference between Corrective Reading 2009 IRI reading scores (538.23) and Corrective Reading 2008 IRI reading scores (627.64) (see Table 4.4). Corrective Reading 2008 students' data and Corrective Reading 2009 students' data based on their gain scores on the IRI are: $t=2.965, \mathrm{df}=55$, pvalue $.004<.05$ 
This result shows that the Corrective Reading participants' performance on average decreased from pre-test to post-test. Explanations for this result are somewhat beyond the data collected for this research. However, possible explanations might be that the smaller number of participants in the Corrective Reading group allowed for greater variance in the scores as compared to the Read 180 group. Another explanation might be that the scores for the pre-test were so high for the pre-test as compared to the Read 180 group; there was a regression to the mean (Fraenkel \& Wallen, 2009). Other potential reasons for the decrease as stated previously are somewhat beyond the data that was collected for this research and would be at best speculative. Additionally, a significant number of ECE students were in this study's reading intervention and the RSPS is not validated on this population.

Additionally, teachers have long suspected that the frequency of mobility of lowperforming students negatively impacts reading achievement, self efficacy, and overall performance of schools. Student mobility is defined as "the practice of students making non-promotional school changes, often during the school year" (Rumberger, 2003, p.6). Engec (2006) found that "frequent mobility negatively affects sixth-grade students' reading achievements" (p. 168). The U.S. Department of Education (1995) reported that low-performing students in middle grades are likely to have changed schools two or more times after entering the first grade. This discontinuity in school attendance jeopardizes the affect reading programs can have on improving self efficacy and student reading gains. Teachers are at a disadvantage when trying to remediate these reading deficits because of the frequency of school changes. Research stated that reasons for frequency of mobility were associated with family problems and students leaving for the advantages 
of educational programs their current school did not offer (Rumberger, 2003; Offenberg, 2004). These changes occur for students in the elementary school years more frequently than for students in high school in urban school districts.

What are the factors that predict overall reading percentage improvement, reading improvement for Read 180 and reading improvement for Corrective Reading? One variable was found to be a mild to moderate predictor of reading percentage improvement at the .05 level, School D, for research questions two, three and four, for which School D, reported gender as an additional predictor of reading improvement. The implications of reporting on School D might lead to analysis that did not occur through data collection and analysis of data that is unsupported by a formal systematic observation of School D. As for gender being a predictor variable for school improvement there are various reports of the performance of girls in outperforming boys in all subject areas by fourth grade. Newkirk (2000) reported that the gap between boys and girls is "comparable to the difference between Whites and racial/ethnic groups that have suffered systematic social and economic discrimination in this country" (p. 295). Furthermore, Purves (1992) found that "gender by itself or in combination with certain home variables was the most powerful predictor of performance, particularly with academic tasks" (p. 201). Research states that "teachers have varied expectations of boys and girls and that such expectations may be associated with student performance" (Auwarter, 2008). Despite these discrepancies in reading performance, researchers should consider the role of the teacher expectations when teaching reading to students. 
Internal and External Threats

Admittedly, an early self-efficacy measurement was not performed for pretest comparison to posttest comparison with low-income children which limited the technical adequacy of these findings. The implications of these results could be strengthened with replication to ensure that a pretest of self-efficacy using the RSPS would ensure generalizability to the total population within the school district. Also, the sample sizes between groups varied for this study and the results were only generalizable to students from low-income backgrounds living in an urban Midwestern school district. Selection of the reading population using only five schools is a threat to generalizability of the study to other counties in Kentucky, based upon the Jefferson County Public School district having a larger number of diverse populations. My affiliation with the school district by being an assistant professor allowed access to the schools, with district and building administrator approval, permissible by each school. Results from a larger random sample of students could yield different results. Threats to following the protocol will need to be considered if there are English as a Second Language (ESL) students or special needs students, who require more time and/or modifications and adaptations to complete the survey, although instructions are included. Requiring students and parents to sign consent forms could allow bias because of populations, English as a Second Language (ESL), may have difficulty reading the consent forms.

\section{Recommendations for Future Research}

Research has documented that gains in reading achievement have an association to improved academic performance and quality of life options that expand beyond the classroom. Unfortunately, low-income students with reading deficits experience 
biological and sociological factors associated with reading achievement. Therefore, policymakers, teachers and parents "need to intensify and expand efforts in addressing the needs of" (Archwamety \& Katsiyannis, 2000, p. 167) low-performing students. Support programs that address health care, environment, housing and schools are needed to curtail these factors that make low-performing students at-risk for reading failure. Although these programs may be in place, an uncertain academic future may still be likely for most students. Teachers, who are able to identify disruptive, deviant and defiant behaviors related to biological factors (e.g. poor schools, impoverished home environment, alcohol and drug abuse,), understand that students are in dire need of early intervention and prevention programs that prepare students for learning and promote socially acceptable behavior in the school environment.

Additional research could focus on determining the best practices in improving the reading gains of boys in U.S. classrooms. The chronicle of literacy gaps for boys is pervasive in education. Research states that as students move into high school "literacy skills play a key role in how well they will perform and, ultimately, their future academic considerations" (Mitchell, Murphy \& Peters, 2008, p.70). The National Assessment of Educational Progress (2004) revealed that boys are achieving at lower rates in reading achievement and as the student moves on through school the gap in literacy achievement widens compared to girls. Educational responses to this pervasive problem have included multiple responses from reading programs that separate by gender to fusing technology with reading pedagogy (Sokal \& Katz, 2006). One point is clear regarding this phenomenon, boys who are at-risk of literacy failure are in need of reading interventions during the early stage of speech and language development for them to avoid dropping 
out of school by grades six through eight. As boys get older and their literacy skills continue to decline, they are $55 \%$ more likely to leave school and become unemployed or underemployed. In the article, Challenging the Gender Divide: Improving Literacy for All (2004), issues dealing with how to diffuse literacy failure for boys are discussed. Recommendations included teachers', parents and librarians restructuring the school environment for boys to recognize literacy as a masculine choice, reorganizing reading classes based on gender, recruiting male teachers to lead reading clubs within the school, and allowing boys' more choice in what they choose to read. Parsons (2004) suggest that teachers' are crucial to literacy introduction by the way they cultivate and nurture literacy within their own classroom. Teacher's who have a poor literacy background will not be as efficacious when introducing and teaching reading strategies to boys' who struggle to read.

The current study focused on assessing a dimension of reading self-efficacy, based upon Progress, Observational Comparison, Self-Feedback, Physiological States and factors that predict reading improvement. Further research should expand on this study by analyzing the effects of reading time that is not affected by the overuse of progress monitoring. This study did not explore this issue. Additionally, future research utilizing curriculum-based assessments that allow for authentic student work should also be considered in assessing student reading and self-efficacy.

Again, this current study focused on the importance of student self-efficacy and factors that improve reading achievement. As the importance of student achievement and teacher accountability remains the focus of the state and federal government, future research will need to focus on the preparation of content area teachers to instruct low- 
performing students in reading pedagogy. Teachers who work with low-performing students should be aware of their expectations, since research indicates their perceptions of low socioeconomically disadvantaged students is generally in the low range (Arguette, 2008). Additional research can examine the socio-cultural predictors of how students will perceive and accept reading (Worrel, Roth \& Galbelko, 2007). If peer groups are important in shaping the attitude of adolescent students, placing the students in positive heterogeneous reading programs should be considered. Also, continued research will need to emphasize the importance of collaborative practices of special education teachers and general education teachers to combine strategy instruction and content area subjects to improve reading achievement for all struggling readers.

Past research has focused on teaching reading. Future research will need to focus on training teachers how to create and interpret assessments and how to remediate reading problems through content instruction (Dennis, 2008) to increase the self-efficacy of low-performing readers. The RSPS provided a measure of four factors associated with self-efficacy, nevertheless, usage of a research instrument whose primary focus is addressing measurement of teacher self-efficacy in implementing reading pedagogy is needed. As well, future research is necessary for the RSPS.

\section{Conclusion}

As an educator, walking into any classroom in the United States we find that students have varying levels of reading proficiency. The concept of self-efficacy has created tremendous research for individuals interested in the mechanisms needed to improve reading pedagogy to benefit low-performing readers. This study focused on self-efficacy, defined as a person's confidence within himself or herself to execute 
strategies that enable them to accomplish a goal (Bandura, 1989). This is accomplished by small successive approximations of reading pedagogy through task analysis which increases the likelihood the individual will generalize this reading skills into other areas of their lives (Heward, 2006).

While the current study focused on self-efficacy and its relationship in improving the reading skills of low-performing readers, the importance of progress monitoring, self feedback, observational comparison and creating a classroom environment conducive for reading were also considered by information reported by students on the RSPS. Although both programs were used to improve reading achievement, neither was significantly different than the other in improving the self-efficacy of the students.

Contrary to self-efficacy theory (Bandura, 1997), it was reasonable to state that Corrective Reading participants in this study decreased in their reading gains because reading instruction did not improve the overall factors associated with self-efficacy. One reason would be the failure of past preschool and elementary schools to provide programming, interventions and strategies for low-income middle school students in the Corrective Reading group before entering middle school. The No Child Left Behind Act's (2002) Early Reading First Program defines high quality, intensive programs as, being operated by full-time staff, at 6.5 hours per day, 5 days a week, for 46 weeks per year, and serving children for two consecutive years before entering kindergarten (U.S. Department of Education, 2005). The importance of early intervention in elementary school of reading problems is essential in closing the achievement gap for low-income students who are educationally at-risk (Luftig, 2003). Edmonds, O’Donoghue, Spano and Algonzzine (2009) report that "children who begin [elementary] school with lower 
literacy skills than their same-aged peers are likely to remain behind their peers as the progress through school" (p. 213). Research has consistently shown that the longer intervention is withheld, the greater the damage to reading achievement for low-income students by fourth grade. Correlates of reading failure include problems with selfefficacy, attitude toward school, and social adjustment (Seifert, 2004). In recent years, with the passage of No Child Left Behind (2001), education policy has shifted from intervention models toward prevention models that are put into place to remediate reading deficits if a child is thought to be experiencing reading failure (Edmonds, O'Donoghue, Spano \& Algozzine, 2009).

Another factor to consider that affects self efficacy is the loss of reading skills by low-performance that occur during the summer. Mraz and Rasinski in Summer Reading Loss (2007) define summer reading loss as “the decline in children's reading development that can occur during summer vacation times when children are away from the classroom and not participating in formal literacy programs" (p. 784). Schools that fail to prepare low-performing students as proficient readers are eligible to receive supplemental educational services through Title I funding. The funding provided by Title I are used to implement research based reading programs for children who are at-risk for reading failure. Luftig (2003) states that students spending a minimum of nine hours in intensive reading instruction for one month can improve their reading gains compared to students who receive no reading instruction and are likely to regress in their reading from 1.5 percent to 16 percent. 


\section{Implications for Educators}

Lee (2002) encourages collaboration of parents and teachers to dialogue with each other in discussing the importance of increasing student self-efficacy. However, constructs that teachers are able to control will increase the capability of their dialogue taking place, mainly their increased understanding of self-efficacy. Teacher's access to research on self-efficacy through teacher education programs and professional development, as well as the RSPS, are one of the instruments that can be used to measure student self-efficacy. Solid content pedagogy that emphasizes multifactored evaluations will enable progress monitoring that is effective in increasing student proficiency (Stecker, Lembke \& Foegen, 2008).

Activities, such as, class wide peer tutoring, corrective feedback, paired reading and appropriate level text will lead students in becoming successful reader (Welsch, 2006). Reading content area teachers should embed reading strategy instruction in all classroom activities (Wheldal \& Madelan, 2000). Administrator, teachers and librarians should consider increasing the emphasis of highly rated school libraries to improve reading proficiency and school wide test scores (Cleveland, 2007).

The Importance of Qualified Teachers

Preparation of teachers has historically been and continues to be of importance to federal and state governments, and to local school districts and communities (DarlingHammond, 2002). The preparation of teachers to work with low-performing populations with literacy problems has become a recent and primary concern (Dalhouse, 2005). Universities and colleges of education that train teachers have been asked to begin to instruct new teachers on how to create fewer discrepancies between low income and 
same age white peers in the classroom in closing the achievement gap (Neil, 2004). Research and policy reports continue to show that students from culturally diverse low income backgrounds are consistently failing to reach proficiency on reading assessments (Snow, Burns \& Griffin, 1998) and are persistently disproportionately labeled at-risk for academic and/or reading failure" (Foorman, 1998). Surprisingly, the recognition of these disparities still leads to low-achieving students not receiving equal access to proper literacy instruction in the U.S. (Shealey \& Lue, 2006). Focus on teacher confidence in working with diverse populations is an important issue in developing sound accountability standards and enhancing education in the U.S. Barnes (2006) states that teachers who are open to constructive criticism and to new ideologies of teaching students from diverse backgrounds are of vital importance in students' success in learning and educational attainment. Problems persist when teachers are not confident in understanding "the world of the children with whom they work in order to better offer opportunities for learning success (Barnes, 2006, p. 86). Efforts in teacher education programs are in motion to integrate cross-cultural competence content and accountability from accreditation agencies for teacher education programs to explicitly address diversity and student achievement, including NCATE (NCATE, 2009).

Many students who come from disadvantaged situations generally are from families who also had challenging academic difficulties during their school years. Studies on poverty have consistently determined that poor parent reading achievement correlates with children having reading deficiencies (Taylor \& Dorsey, 1988). Children who attend schools where they receive a poor foundation in the area of reading will have a harder time receiving remediation in U. S. public schools (Shealey \& Lue, 2006). Thus, 
teachers, and particularly reading teachers, are critical for intervention to break a cycle of poor literacy achievement (Delpit, 2003).

Current research also suggests that schools serving disproportionately high numbers of low-performing students often mandate less classroom instructional time for literacy during the school day than schools that serve mainstream students (Francis et.-al. 1996). Furthermore, schools serving low-performing students often teach reading through discrete reading which emphasizes rote memorization (Hammond, Hoover, McPhail, 2005, \& Strickland, 1994). Equally important, is Strickland's (1995) assessment that this learning leaves low-income students "not knowing how to use...information, how to learn on their own, to think for themselves, solve problems, and critique their own work and the work of others" (p. 331). Research in the past ten years has consistently proven that quality literacy instruction will enhance the achievement of low-performing students (Snow, Burns, \& Griffin, 1998).

The relationship between self efficacy and reading success; the current state of literacy for low-performing students in U.S. schools; and factors that continue to contribute to or have promise to ameliorate the achievement gap in reading assessment scores merit additional research. This study has contributed to this body of literature. 


\section{REFERENCES}

Abrahams, David. http://www.socialresearchmethods.net/tutorial/Abrahams/true.htm

Abadiano, R. H., \& Turner, J. (2005). Early Literacy and Developmentally Appropriate Practice: Closing the Achievement Gap. Review of Research in the Classroom. The New England Association. 41(2) pp. 60-6.

Al Otaiba, S., \& Fuchs, D. (2006). Who Are the Young Children for Whom Best Practices in Reading Are Ineffective? Journal of Learning Disabilities. (39) 5, pp. 414-431.

Alderman, M.K. (2004). Motivation for Achievement: Possibilities for teaching and learning. $2^{\text {nd }}$ ed. Mahwah, NJ: Erlbaum.

Alexander, K., Entwisle, D., \& Bedinger, S. (1994). When Expectations Work: Race and Socioeconomic Differences in School Performance. Social Psychology Quarterly. (57) 4, pp. 283-299.

Alson, A. (2003). The Minority Student Achievement Network. Educational Leadership. pp. 76-78.

Amato, P.R., \& F. Fowler. (2002). Parenting Practices, Child Adjustment, and Family Diversity. Journal of Marriage and Family. (64) 3, pp. 703-20.

Ashton, P. (1984). Teacher efficacy: A Motivational Paradigm for Effective Teacher Education. Journal of Teacher Education. (35), pp. 28-32,

Atwood, D. Joan. (2006) Mommy's Little Angel, Daddy's Little Girl: Do You Know What Your Pre-Teens Are Doing? The American Journal of Family Therapy. (43), pp. 447-467.

Akers, Ronald. (2003). Tough Fronts: The Impact of Street Culture on Schooling. Contemporary Sociology. Washington. (32), 3, pp. 372. 
Alexander,L. Karl., Entwisle, Doris., \& Bedinger, D. Samuel. (1994). When Expectations Work: Race and Socioeconomic Differences in School Performance. Social Psychology Quarterly. 1994, (57) 4, pp. 283-299.

Alexander, L. Karl., \& Entwisle, Doris. (1988). Achievement in the First 2 Years of School: Patterns and Processes. Monographs of the Society for research in Child Development. (53) 2.

Alger, L. Christianna. (2007). Engaging Student Teacher's Hearts and Minds In The Struggle to address (il)literacy in content area classrooms. Journal of Adolescent \& Adult Literacy.

Allington, R. L. (2001). What Really Matters For Struggling Readers: Designing Research-Based Programs. New York: Longman.

American Federation of Teachers Report, Teaching Reading is Rocket Science: What Expert Teachers of Reading Should Know and Be Able To Do (Retrieved March 15, 2009 from http://www.aft.org/pubs-reports/downloads/teacher/rocetsci.pdf) American Federation of Teachers (1999). Teaching Reading Is Rocket Science. (Washington, DC, AFT).

Au, K. H. (1998). Social Constructivism and the School Literacy Learning of Students of Diverse Backgrounds. Journal of literacy Research. (20), 297-319.

Au, K. H. (2001). Culturally Responsive Instruction As A Dimension of New Literacies. Reading Online. 5(1).

Auwater. E. A. \& Arugetter, S. M. (2008) Effects of Student Gender and Socioeconomic Status on Teacher Perceptions. The Journal of Education Research. (101) 4. 
Baker, F. (1991). Saving our Kids From Delinquency, Drugs and Despair. NewYork: Harper Collins.

Bandura, A. (1986). Social Foundations of Thought and Action. Englewoord Cliffs, NJ: Prentice-Hall.

Bandura, A. (1989). Human Agency In Social Cognitive Theory. American Psychologist. (44).

Bandura, A. (1997). Self efficacy: The Exercise of Control. New York: W.H. Freeman and Company.

Banks, J.A. (2005). Multicultural education: Characteristics and goals. In J.A., Banks \& C.A. M. Banks (Eds.), Multicultural education: Issues and Perspectives $\left(5^{\text {th }}\right.$ ed.). pp. 3-30. Hoboken, NJ:Wiley.

Barr, Robert D., \& Parret, William H. (1997a). How To Create Alternative, Magnet, and Charter Schools That Work. Bloomington, IN: National Educational Service.

Barr, R., Parrett, W. (2001). Hope Fulfilled For At-Risk and Violent Youth K-12: Programs That Work. Allyn \& Bacon $2^{\text {nd }}$ edition.

Barkley, M., Jordan. (2006). Reading Education: Is Self-Efficacy Important? Reading Improvement. (43) 4.

Barton, Paul. E. (2004). Why Does The Gap Persist? (62) 3 pp. 8-13 Barnes, J. Charline. (2006). Preparing Preservice Teachers to Teach in a Culturally Responsive Way. The Negro Educational Review. (57)1. Baumeister, R.F. (1990). Suicide As Escape From Self. Psychological review, (99), pp. 90-113. 
Beyers, M. Jennifer, Loeber, Rolf, Wikstrom, Per-Olfof H., \& Loeber, Magda. (2001). Journal of_Abnormal Child Psychology. New York. (29) 5.

Billings-Ladson, Gloria. (2006). From the Achievement Gap to the Education Debt: Understanding Achievement in U.S.Schools. Educational Researcher. (35) 7.

Birnbaum, S. (2001). Law and Order and school: Daily Life in the Educational Program for Juvenile Delinquents, Philadelphia: Temple University Press. Blue Ribbon Schools Report (1993).

Boersma, F.J., Chapman, J.W., \& MacGuire, T.O. (1979). The Student Perception of Ability scale: an Instrument For Measuring Academic Self-Concept In Elementary School Children. Educational and Psychological Measurement. (39).

Boling, J. Charlotte., \& William, Evans. (2008). Reading Success in the Secondary Classroom. Preventing School Failure. (52) 2.

Boulay, R. (2005). The Relationship between Parental Involvement and Immigrant students success among the Immigration Population in Jefferson County Public School System.

Bracy, G. (2005). Investing in preschool. Annual Editions: Early Childhood and Elementary Literacy. Dushkin McGraw Hill.

Brendtro, L., Ness, A., \& Mitchell, M. (2001). No disposable kids. Bloomington, IN: National Education Service.

Brofenbrenner, U. (1979). The ecology of human development. Experiments by nature: Experiments by nature and design. Cambridge, MA: Harvard University. 
Brookings Institute. (2002). A Competitive Vision for the Regional City of Louisville on Urban and Metropolitan Policy for the Greater Louisville.

Browder, D. M., \& Snell, M. E. (2000). Functional academics. In M.E. Snell \& Brown, Instruction of students with Severe Disabilities ( $5^{\text {th }}$ ed.), pp. 493-542. Upper Saddle river, NJ: Merrill/Prentice Hall.

Brown-Powell, A. (2004). Can you be a teacher of literacy if you don't love to read? Journal of Adolescent and Adult Literacy. (47) 4.

Bogner, K., L. Rl, \& Pressley, M. (2002). How grade 1 teachers motivate literacy activity by their students. Scientific Studies of Reading 6 (2).

Boon, T., \& Spencer, G. V. (2006). Influencing Learning Experiences: Let's Ask the Students. Intervention in School and Clinic. 41 (4).

Bullis, M., \& Walker, H. M. (1996). Characteristics and causal factors of troubled youth. In C. M. Nelson, R. B. Rutherford, \& B. I. Wolford (Eds.), Comprehensive and collaborative systems that work for troubled youth: A National Agenda. pp.1528. Richmond, KY: National Juvenile Detention Association. Bursuck, D., W., Smith, T., Munk, D., Damer, M., Mehlig, L. \& Perry, J. (2004). Evaluating the Impact of a Prevention-Based Model of Reading on Children Who Are At Risk. Remedial and Special Education. 25(5).

Buzi, S. Ruth., Tortolero, R. Susan., Roberts, E. Robert., Ross, W. Michael., Addy, C. Robert., \& Markham, M. Christine. (2003). The Impact of a History of Sexual Abuse on High Risk Sexual Behaviors among Females Attending Alternative Schools. (38) 152. 
Carlson, C. D., \& D. J. Francis. (2002). Increasing the reading achievement of at-risk children through direct instruction: Evaluation of the rodeo Institute for Teacher Excellence(RITE). Journal of Education for Students Placed At Risk. 7 (2).

Campbell, D. T.\& Stanley C. J., Experimental and Quasi-experimental Designs for Research; Rand McNally \& Company Chicago, 1963.

Carr, Alan. (2004) Interventions for post-traumatic stress disorder in children and adolescents. Pediatric Rehabilitation. Pediatric Rehabilitation. (7) 4.

Chapman-Stanton, T. L., Chapman., D., \& Kaiser, K., . (2004) Cumulative Risk and Lowincome Children's Language development. Topics in Early Childhood Special Education. (24)4.

Christ, J., T. \& Christ, J. (2006) Application of an interdependent Group Contingency Mediated by an Automated Feedback Device: An Intervention Across Three High School Classrooms. School Psychology Review. (35) 1, pp. 78-90.

Cleveland, Laurie. (2007). Surviving the Reading Assessment Paradox. Teacher Librarian. (25) 2.

Cohen, R., Kincaid, D., \& Child, K. (2007). Measuring schoolwide Positivie implementation. Journal of Positive Behavior Intervention. (9) 4, pp. 203-213.

Coladarci, T. \& Berton, W. (1997). Teacher efficacy, Supervision and Special education resource-room teacher. The Journal of Education Research.(90) pp. 230-239.

Coleman, P. K., \& Hildebrandt, K. (2000). Parenting Self Efficacy among Mothers of School-Age Children: Conceptualization, Measurement, and Correlates. Family Relation. (49) 1. pp. 13-24. 
Compton-Lily, C. (2002). "Staying on Children"; Challenging Stereotypes about Urban Parents". Language Arts. (77) 5, pp. 420-427.

Convoy, M., Sutherland, K., Snyder, A., \& Marsh, S., (2008) Teaching Exceptional Children, (40) 6, pp. 24-30.

Cleveland, Darrell. (Fall 2003) Beating the odds: Raising academically successful African American males. Journal of Men's Studies.

Coleman, M., \& Vaughn, S. (2000). Reading interventions for students with emotional/behavioral disorders. Behavioral Disorders. (25), pp. 93-104.

Craig, H.K., \& Washington, J.A. (2002). Oral language expectations for African American preschoolers and kindergarteners. American Journal of SpeechLanguage Pathology, 11, 59-70. (12) 1; pg. 85.

Craven, R.G., H. W. Marsh, \& R. L. Debus. (1991). Effects of internally focused feedback and attributional feedback on the enhancement of academic selfconcept. Journal of Educational Psychological. (83) pp. 17-27.

Cromer, R. K., \& Ericsson-Sachs, N. (2006). The Association Between Childhood Abuse, PTSD, and the Occurrence of Adult Health Problems: Moderation via Current Life Stress. Journal of Traumatic Stress. (19) 6, pp. 967-971.

Condron, J. D., \& Roscigno, J. V. (2003) Disparities Within: Unequal Spending and Achievement in an Urban School District. Sociology of Education. (76) pp. 1836.

Connel, A., Dishion, T.J., Yasui, M. \& Kavanagh, K. (2007). An Adaptive approach to family intervention; Linking engagement in family centered intervention to 
reduction in adolescent problem behavior. Journal of Consulting and Clinical Psychology. (75) 4, pp. 568-79.

Covington, M.V. (1992). Making the Grade: a self worth perspective on motivation and school reform. Cambridge: Cambridge University Press.

Craig, K. H., Connor, M. C., Washington, A. J. (Jan, 2003) Early Positive Predictors of Later Reading Comprehension for African American Students: A Preliminary Investigation. Language, Speech, and Hearing Services in Schools. (34), pp. 3143.

Craig, K. H., Connor, M. C., \& Wasington, A. J. (2003). Factors affecting Urban African American high school students achievement in Reading. Urban Education, (43) 2, pp. 154-171.

Dalhouse-D. W., (2005). No Child Left Behind: Key Issues and Instructional Implications for Teachers of African-American Children. Reading Horizons,(45) 3.

Darling-Hammond, L. (2000a). Reforming teacher preparation and licensing: Debating the evidence. Teachers College Record. (102) 1, pp. 28-56.

Darling-Hammond, L. (2000). Teacher quality and student achievement: A review of state policy evidence. Educational Policy Analysis Archives. (8) 1.

Darling-Hammond, L., Chung, R., \& Frelow, F. (2002). Variation in teacher preparation: How well do different pathways prepare teachers to teach? Journal of Teacher Education. (53) 4, pp. 286-302.

Darling-Hammond, L., \& MacDonald, M. (2000). Where there is learning there is hope: The preparation of teachers at the Bank Street College of Education. In L. 
Darling-Hammond (Ed.), Studies of excellence in teacher education: Preparation at the graduate level. pp. 1-95). Washington, DC: American Association of Colleges for Teacher Education.

Darling-Hammond, L. \& Sykes, G. (2003). Wanted: A national teacher supply policy for education: The right way to meet the 'highly qualified teacher' challenge.

Educational Policy Analysis Archives. (11) 33.

Darling-Hammond, L. \& Youngs, P. (2002). Defining “highly qualified teachers:" What does "scientifically-based research" actually tell us? Educational Researcher. (31) 9 , pp. 13-25.

Daniel, S. S., Walsh, K. A., Goldston, B. D., Arnold, M. E., Reboussin, A. B., \& Wood, B. F. (2006). Journal of Learning Disabilities. (39) 6, pp. 507-514.

Davis, W. E., \& McCaul, E. J. (1991). The emerging crisis: Current and projected status of children in the United States. Orono, ME: University of Maine, Institute for the Study of At-Risk Students.

Delpit, L. (2003). Educators as "Seed People" growing a new future. Educational Researcher, 32 (7), 14-21

Denton, A. C., Fletcher, M. J., Anthony, L. J., \& Francis, J. D. (2006) Journal of Learning Disabilities. (39) 5 pp. 447-466.

Dennis, V. Danielle. (2008). Are assessment data really driving middle school reading instruction? What we can learn from one student's experience. Journal of Adolescent and Adult Literacy. (51) 7. 
Downer, J., Rimm-Kaufman, S. \& Pianta, R. (2007) How do Classroom Conditions and Children's Risk for School Problems Contribute to Children's Behavioral Engagement in Learning? School Psychology Review. (36) 3, pp. 413-432.

Dunifon, Rachel., \& Duncan, J. Long Run Effects of Motivation on Labor Market Success. Social Psychology Quarterly. (61) pp. 33-48.

Ede, Anita. (2006) Scripted Curriculum: Is It a Prescription for Success? Childhood Education. (83) 1 pp. 29-33.

Edmonds, Ellen., O’Donoghue, Cathleen., Spano, Sedra. \& Algozzine, F. R. (2008). Learning When School Is Out. The Journal of Educational Research. (102) 3.

Ehrensaft, K. Miriam. (March, 2005) Interpersonal Relationships and Sex Differences in the Development of Conduct Problems. Clinical Child and Family Psychology Review. (8)1.

Ellis, J. B., Bates, E. J., Dodge, A. K., Fergusson, M. D., Horwood, L. J., Pettit, S. G., \& Woodward, L. (2003) Does Father Absence Place Daughters at Special Risk for Early Sexual Activity and Teenage Pregnancy? Child Development. (74) 3, pp. 801-821.

Engac, N. (2006). Relationship Between Mobility and Student Performance and Behavior. The Journal of Educational Research. (99) 2.

Epstein, M. H., Hertzog, M.A., \& Reid, R. (2001). The Behavioral and Emotional Rating Scale: Long term test-retest reliability. Behavioral Disorders. (26), pp. 314-320. Emsbarger, S.C. (2002). Simple, affordable, and effective strategies for prompting reading behavior. Reading and Writing Quarterly. 18 (3) pp. 279-84. 
Estes-Bailey, M. (2006). Charter Schools: Do They Work For Troubled Students. Preventing School Failure. (51) 1, pp. 55-61.

Evans, E.D., \& Triblle, M. (1986). Perceived teaching problems, self-efficacy, and commitment to teaching among preservice teacher. Journal of Educational Research. (80), pp. 81-85.

Eccles, J. S., Lord, S., \& Buchanan, C. M. (1996). School transitions in early adolescence: What are we doing to our young children? In J. A. Graber, J. Brooks-Glenn, \& A. C. Peterson (Eds.). Transitions through adolescence: Interpersonal domains and context pp. 251-284. Hillsdale, NJ: Erlbaum.

Educational Professional Standards Board of Kentucky. (2009). www.kyepsb.net Ezarik, M., (2004). Study: Low marks for Direct Iinstruction. Direct Administration. (40) 4 , pp. $63-63$.

Farstrup, A.E. (2002). There is more to effective reading instruction than research. International Reading Association.

Finn, P. (1999). Literacy with Attitude-Educating Working-Class Children in their own Self-Interest. Albany, NY: SUNY Press.

Firmin, M., Hwand, C., \& Clark, S. (2000) Learned Helplessness: The Effect of Failure on Test-Taking. Education. (124) 4.

Flores, M., \& Kaylor M. (2007). The effects of a direct instruction program on the fraction performance of middle school students at risk for failure in mathematics. Journal of Instructional Psychology. (34)(2), pp. 78-87.

Flowers, L. (2007). Recommendations for Research to Improve Reading Achievement for African American Students. Reading Research Quarterly. (42) 3. 
Ford, E. T. (September 1997). Effects of stereotypical television portrayals of AfricanAmericans on person perception. Social Psychology Quarterly. (60)3, pp. 266

Foster, M. (1997). Black teachers on teaching. (New York, New Press).

Francis, D. J., Shaywitz, S.E., Stuebing, K.K., Shywitz, B. A., \& Fletcher, J.M. (1996). Developmental lag versus deficit models of reading disability: A longitudinal, individual growth curve analysis. Journal of Educational Psychology. (88), pp. 317.

Freedman, L., \& Carver, C. (2007, May) Preservice Teacher Understandings of Adolescent Literacy Development: Nä̈ve Wonder to Dawning Realization to Intellectual Rigor. Journal of Adolescent and Adult Literacy. pp. 50-58.

Freire, P. (1998). Teachers as cultural workers: Letters to those who dare to teach. Boulder, CO: Westview Press.

Fuchs, D., \& Otaiba-Al, S. (2006) Who Are the Young Children for Whom Best Practices in Reading Are Ineffective? An Experimental and Longitudinal Study. Journal of Learning Disabilities. (39), 5, pp. 414-431.

Fuhrman,S., \& Elmore, R. (2001) Holding Schools Accountable: Is It Working. Phi Delta Kappa International. (83),1, pp. 67-70, 72.

Gargiulo, M., Richard. (2008) Special Education in Contemporary Society. Third Edition. Sage Publications.

Gartland, D. (1993). Elementary teacher-parent partnerships: Effective communication strategies. LD Forum, (18)3, pp. 40-42. 
Gay, G. (2002). Culturally Responsive in special education for ethnically diverse students: Setting the stage. International Journal of Qualitative Studies in Education. (15), pp. 613-630.

Girolametto, L., Weitzman, E., Lefebvre, P., \& Greenberg, Janice. (2007). The Effects of Inservice Education to Promote Emergent Literacy in Child Care Center: A Feasibility Study. Language, Speech, and Hearing Services in Schools. (38), pp. $72-83$.

Gilliam, D. Frank, Valenton, A. Nicholas, Beckham, \& N. Matthew. (2002) Where You Live and What You Watch: The Impact of Racial Proximity and Local Ttelevision News on Attitudes about Race and Crime. Political Research Quarterly. (55) 4, pp. 755 .

Goals 2000: Educate America Act. (1994). Washington, D.C.. U.S. Department of Education.

Gonzales, N.A., A. M. Cauce, R.J. Friedman, \& C.A. Mason. (1996). Family, Peer, and Neighborhood Influences on Academic Achievement Among African-American Adolescents: One-Year Prospective Effects. American Journal of Community Psychology (24) 3, pp. 365-87.

Gosa, L. T., Alexander, L. K. (2007). Family (Dis) Advantage and the Educational Prospects of Better Off African American Youth: How Race Still Matters. Teachers College Record. (109) 2, pp. 285-321.

Govender, K., Moodley, K. (2004). Maternal Support and Adolescent Self-Esteem: A comparative study of urban children living in formal and informal housing. Journal of Children \& Poverty. (10) 10. 
Griffin, W. B. (2002). Academic Disidentification, Race, and High School Dropouts. The University of North Carolina Press. pp. 71-79.

Grossman, J. B., \& Garry, E. (1997). Mentoring, a proven delinquency Prevention Strategy. OJJDP Bulletin, U.S. Department of Justice, Office of Juvenile Justice and Delinquency Prevention.

Guithrie, J., Wigfield, A., Metsala, J. L., \& Cox, K. E. (1999). Motivational and Cognitive Predictors of Text Comprehension and Reading Amount. Scientific Studies of Reading, (3), pp. 231-256.

Gumpel, T.P., \& Schlomit, D. (2000). Exploring the efficiency of self-regulation as a possible alternative to social skills training. Behavioral Disorder. (25), pp. 131141.

Guzman, Betsy. (2001). The Hispanic Population. U.S. Census Bureau. pp. 2-10.

Greater Louisville Inc. (2003) Report on Education. pp. 4-22.

Gursky, D. (1992). Spare the Child. Teacher Magazine, (3) 5, pp. 17-19.

Gushue, V. George,, Clarke, P. Christine., Pantzer, M. Karen, Scanlan, R.L. Kolone. R.L. (2006). Self-Efficacy, Perceptions of Barriers, Vocational Identity, and the Career Exploration Behavior of Latino/a High School Students. The Career Development Quarterly. (54), pp. 307-317.

Hallinan, T. M., \& Khmelkov, T. V. (2001). Recent Developments in Teacher Education in the United States of America. Journal of Education for Teaching. (27) 2.

Hanson, T.L., S. McClanahan., \& E. Thomson. (1997). Economic Resources, Parental Practices and Children's Well Being. In Consequences of Growing Up Poor. New Yourk: Russell Sage Foundation. 
Hamilton, K. (2002). Race in the CollegeClassroom. Black Issues in Higher Education Reston: (19), 2, pp. 32 .

Hanlon, E. T. (2002). An Early Community Based Intervention for the Prevention of Substance Abuse and other Delinquent Dehavior. Journal of Youth and Adolescence. (31), 6 .

Harachi, W. T., Fleming, B. C., White, R. H., Ensminger, E. M., Abbott, D. R., Catalano, F. R., \& Haggerty, P. K. (2006). Aggressive Behavior among Girls and Boys During Middle Childhood: Predictors and Sequelae of Trajectory Group Membership. Aggressive Behavior. (32), pp. 279-293.

Harper, C. C., \& McLanahan, S. Sara. (2004). Father Absence and Youth Incarceration. Journal of Resarch on Adolescence. (14) 3, pp. 396-397.

Harter, S, Rumbaugh, N. Whitesell, \& Kowalski, P. (1992). Individual Differences in the Effects of Educational Transitions on Young Adolescent's Perceptions of Competence and Motivational Orientation. American Educational Research Journal, (29) 4, pp. 777-807.

Hawkins, D. (1999). Violence in America. Cambridge, England: Cambridge University Press.

Henk, W. A. \& Melnick, S. A. (1995). The Reader Self-Perception Scale (RSPS) : A new tool for measuring how children feel about themselves as readers. Research Library. The Reading Teacher. (48) 6.

Henson, D. (1998). Making peace: A Narrative Study of Bilingual Liaison, A School, and A Community. Paper presented at American Educational Research Association, San Diego, CA. 
Henson, R. K. (2002). From Adolescent Angst to Adulthood: Substantive Implications and Measurement Dilemmas in the Development of Teacher Efficacy research. Educational Psychologist, (37), pp. 137-150.

Heward, L. W. (2006). Exceptional Children: An Introduction to Special Education. $8^{\text {th }}$ edition. Pearson-Merrill, Prentice Hall

Heyman, W.B. (1990). The self-perception of a learning disability and its relationship to academic self-concept and self-esteem. Journal of Learning Disabilities, (23), 8, pp. $472-475$.

Hixon, J., \& Tinzmann, M.B. (1990). Who are the "at-risk" students of the 1990s?

Retrieved from North Central Regional Educational Laboratory web site:http://www.ncrel.org/sdrs/areas/rpl esys/equity.html.

Hochschild, L. Jr. (2003). Social Class in Public Schools. Journal of Social Issues. (59), 4, pp. $821-840$.

Holmes, K., Powell, S., \& Holmes, S. (2007). Readers and Book Characters: Does Race Matter? The Journal of Educational Research. (100), 5.

Housego, B. (1992). Monitoring student teachers' feelings of preparedness to teach personal teaching efficacy and teaching efficacy in a new secondary teacher education program. Alberta Journal of Educational Research, (38), pp. 49-64.

Houtveen, A. A. M., \& Van de Grift, W. J. C. M. (2007). School Effectiveness \& School Improvement. (18) 2, pp. 173-190.

Howarth, D. (2004). Mountain Geography for Life and Standards-Based Education in the Commonwealth of Kentucky. The Social Studies. 
Ivarsson, T., Broberg, G. A., Arvidsson, T., \& Gillberg, C. (2005). Bullying in adolescence: Psychiatric problems in victims and bullies as measured by the youth Self report (YSR) and the Depression Self-Rating Scale (DSRS). Nord J. Psychiatry. (59) 5.

Invernizzi, A. M., Landrum, J. T., Howell, \& L. J., Warley. (2005). Toward the peaceful coexistence of test developers, policymakers, and teachers in an era of accountability. The Reading Teacher. (58), 7.

Jackson, Y. (2002). Mentoring for delinquent children: an outcome study with young adolescent children. Journal of Youth and Adolescence. (31), 2.

Jarrett, R.L. (1997). African American family and parenting strategies in impoverished neighborhoods. Qualitative Sociology.(20),1. pp. 275-88.

Jarvis, M. (1996). Personalizing high school. Education Digest. 1996

Jencks, C., \& Phillips, M. (1998). The Black-White test score gap. Washington, DC: Brooking Institute.

Jones, J. D., Forehand, R., Brody, G., \& Armistead, L. (2002). Psychosocial Adjustment of African American Children in Single Mother Families: A Test of Three Risk models. Journal of Marriage and Family. (64), 1 pp. 105.

Johnson, Dan. (1999). The Futurist. Washington: Dec 1999. (33), 10 pp. 11.

Johnson, M. (2002). Teacher: From victims of change to agents of change. Education Review, 16, 56-61.

Karoly, K A., Greenwood, P.W., Everingham, S. S., Hoube, J., Kilburn, M. R., Rydell, C. P., Sanders, M., \& Chisea, J. (1998). Investing in our children: What We Know 
and Don't Know About the Costs and Benefits of Early Childhood Interventions. Santa Monica, CA: RAND.

Kavale, K.A., \& Forness, S. R. (2000). History, Rhetoric and Reality: Analysis of the Inclusion Debate. Remedial and Special Education. (21), pp. 279-296.

Kelly, L.G., \& Chad, S.D. (1989). Retention versus Social Promotion: Schools Search for Slternatives. Harvard Education Letter. (15)10, pp. 1-3.

Kentucky Department of Education (2002).

Kentucky Education Reform Act (1990).

King, K. (2002). Increasing Self Esteem and School Connectedness Through a Multidimensional Mentoring Program. Journal of School Health. (72), 7.

Kim, T., \& Axelrod, S. (2005). Direct Instruction: An Educators' Guide and Plea for Action. The Behavior Analyst Today. (6) 4, pp. 111-120.

Kober, N. (2001). It Takes More Than Testing: Closing the Achievement Gap. Washington, DC. Center on Education Policy.

Kohn, A. (1999). The Schools Our Children Deserve. New York: Houghton Mifflin Company.

Konold, E. K., Miller, P. Miller., \& Konold, B. K. (2004). Using Teacher Feedback to Enhance Student Learning. Council for Exceptional Children. (36), 6.

Kourea, L., Cartledge, G., \& Musti-Rao, S. (2007). Improving the Reading Skill of Urban Elementary Students Through Total Class Peer Tutoring. Remedial and Special Education. (28) 2, pp. 95-107.

Kozol, J. (1991). Savage Inequalities: Children in American schools. New York: Harper Collins. 
Krejcie, R.V., \& Morgan, D. W. (1970). Determining Sample Size for Research Activities, Educational and Psychological measurement, (30), pp. 607-610.

Krovetz, M. L. (1999). Fostering Resiliency: Expecting All Students To Use Their Minds and Hearts Well. Thousand Oaks, CA: Corwin Press, Inc.

Kruger, L. J. (1997). Social Support and Self Efficacy in Problem Solving Among Teacher Assistance Teams and School Staff. Journal of Educational Research, (90), pp. 164-168. Retrieved October 15, 2002, form Expanded Academic ASAP database.

Kuder, S. J. (2001). Language Abilities and Arogress In a Direct Instruction Reading Program for Students with Learning Disabilities. Journal of Learning Disabilities. (24) 6, pp. 124-127.

Kunjufu, J. (1983) Countering the Conspiracy To Destroy Black Boys. African American Images, pp. 31

Ladson-Billings, G. (1997). The Dreamkeepers: Successful Teachers of African American Children. San Francisco, CA: Jossey-Bass.

Lane, J. Lane, M. A., \& Kyprianou, A. (2004). Self-Efficacy, Self Esteem and Their Impact on Academic Performance. Social Behavior and Personality, (32)3, pp. 247-256.

Lane, Lynne-Ka., Little M. A., Rhodes- Redding, J., Phillips, A., \& Welsh, T. M. (2007). Outcomes of a Teacher-Led Reading Intervention for Elementary Students at Risk for Behavioral Disorders. Exceptional Children. (74). 1, pp. 47-70

Landsman, . (2004). Confronting the Racism of Low Expectations. Educational Leadership. 
Leonard, K., Tracy, P., \& Howell, C. J. (2001). Serious, violent, and chronic juvenile offenders: The relationship of Delinquency career types to adult criminality. Justice Quarterly, (18), 3, pp. 449.

Lee, J. (2002). Racial and Ethnic Echievement GapTtrends: Reversing the Progress Toward Equity? Education Researcher. (31)1, pp. 3-12.

Lezotte, L. (1998-1999). Home-school relations. Effective Schools: Research Abstracts, (13)7, pp. 1-2.

Lindo, E. J. (2006). The African American Presence in Reading Intervention Experiments. Remedial and Special Educators. (27), 3, pp. 148-153.

Linnenbrink, E. A., \& Pintrich, P. R. (2003). The Role of Slf-Eficacy Beiefs $n$ Sudent Egagement and Larning in the Cassroom. Reading \& Writing Quarterly. Over Coming Learning Difficulties, (19), pp. 119-137.

Lipsitt, P. L. (2004). Behavior Kills: Controlling Hurtful Behavior. The Brown University Child and Adolescent Behavior Letter. (20), 2, pp. 8.

Maag, J.W., \& Behrens, J. (1989). Depression and Cognitive Self Statements of Learning Disabled and Seriously Emotionally Disturbed Adolescents. The Journal of Special Education, (23), pp. 17-27.

Marchand-Martella, N.E., Martella, R.C., Havis, \& Przychodzin, Angela. Making the Difference. (2000) The Research Base and Validation of SRA's Corrective Reading Program. McGraw-Hill.

Margois, H., McCabe, P,. (2006). Improving Self Efficacy and Motivation: What to Do, What to Say. Intervention in School and Clinic. (41), 4, pp. 218-227. 
Mathes, G. P., Durodola-Pollard, D. S., Hagan-Cardenas, E., Thompson-Linan, S., \& Vaughn, S. (2007). Language, Speech, and Hearing Services in Schools. (38), pp. 260-271.

Major, M. E. (2006). Secondary Teachers as Cultural Mediators forLlanguage Minority Students. Clearing House. (80), 1, pp. 29-32

Marzano, R. (2003). Classroom Management That Works; Research Based Strategies for Every Teacher. Association for Supervision and Curriculum Development.

May, F., \& 1. Rizzardi. (2002). Reading as Communication. $6^{\text {th }}$ ed. Upper Saddle River, NJ: Merrill Prentice-Hall.

MacArthur Network on SES \& Health Web site: www.macses.ucsf.edu

McCabe, P. P. (2006). Convincing Students They Can Learn to Read: Crafting Self Efficacy Prompts. The Clearing House. (79), 6, pp. 252-257.

McClelland, J., Dahlerg, K., \& Pilhal, J,. (2002). Learning in the ivory tower: Students' embodied experience. College Teaching. (50), 1.

McDonnel, L. (1997). Educating One and All: Students with Disabilities and StandardsBased Reform. National Academy Press, 1997.

McPartland, J. M., \& Slavin, R. E. (1990). Policy perspective: Increasing Achievement of At-Risk Students at Each Grade Level. Washington, DC: U. S. Department of Education.

McPherson, K. (2007). Harry Potter and the Goblet of Motivation. Teacher Librarian. (34), 4 pp. $71-74$

Meyer, H.D. \& Rowan, B. (2006). Institutional Analysis and the Study of Education. State University of New York Press. 
McKenna, M.C., Dennis J. Kear, \& Ellsworth R.A. (1995). Children's Attitudes toward Reading: A National Survey. Reading Research Quarterly, (30), 4, pp. 934-956.

Miller, J.G. (1996). Search and Destroy: African-American males in the criminal justice system. New York: Cambridge University Press

Miller, L. S. (2003). Working more productively to produce similar patterns of educational performance among racial/ethnic groups in the United States. New York; Columbia University, ERIC Clearinghouse on Urban Education. (ERIC Document Reproduction Service No. ED482657)

Milich, R., McAninch, C.B. \& Harris, M.J. (1992). Effects of Stigmatizing Information on Children's Peer Relations: Believing Is Seeing. School Psychology Review. (21)3, pp. $400-409$.

Montgomery, D,. (2005). Communication Without Harm: Strategies to Enhance ParentTeacher Communication. Teaching Exceptional Children.

Moore, J.L. (2002). Recruitment is not Enough; Retaining African American Students in Gifted and Talented. Gifted Child Quarterly. (49), 1, pp. 51-67.

Moore, K. A, Vandivere, S., \& Redd, Z. (2006). A Sociodemographic Risk Index. Social Indicators Research Series. (27), pp. 45-81.

National Assessment of Educational Progress (1994)—Reading: A First Look.

Washington, D.C.: National Center for Education Statistics.

National Assessment of Educational Progress (2003).

National Center for Education Statistics. (2001). Education achievement and Black-White Inequality. Washington, DC: Department of Education.

National Council for the Accreditation of Teacher Education (2009). 
National Reading Panel. (2000). Evidence based reading instruction. Putting the National Reading Report into Practice. Newark, DE: International Reading Association.

National Urban Alliance.(2000). National Urban Alliance Professional Development Model for Improving Achievement in the Context of Effective Schools Research. Journal of Negro Education. (69), 4, pp. 305-322.

Neill, W. M. (2006). Highly Qualified Teachers: Provisions, Problems, \& Prospects. Catalyst For Change. (34), 2,

Nelson, J. M., \& Manset-Williamson, G. (2006). The Impact of Explicit, SelfRegulatoryRreading Comprehension Instruction on the Reading-Specific SelfEfficacy, Attributions, and Affect of Students with Reading Disabilities. Learning Disability Quarterly. (29), pp. 213-230.

Neuman, S., \& Celano, D. (2001). Access toPprint in Low Iincome and Middle-Income Communities. Reading Research Quarterly. (36) 1, pp. 8-26.

Newkirk, T. (2001). The Revolt Against Realism: The Attraction of Fiction for Young Writers. Elementary School Journal. (101) 4, pp. 467-477.

No Child Left Behind Act (2001).

Ogbu, J. (2002). Black-American Students and the Academic Achievement Gap: What Else You Need to Know. Journal of Thought. (37) 4, pp. 9-33.

Page, R.N. (1991). Lower-Track Classrooms: A Curricular and Cultural Perspective. New York: Teachers College Press.

Papalewis, R. (2004). Struggling Middle School Readers: Successful, Accelerating Interventions. Reading Improvement. (41) 1. 
Parsons, L. (2004). Challenging the Gender Divide: Improving literacy for All. Teacher Librarian. (32), 2.

Payne, S. R. (1994). The Relationship Between Teachers' Beliefs and Sense of Efficacy and Their Significance to Urban LSES Minority Students. Journal of Negro Education. (63), 2, pp. 181-196.

Phillips, V. (1986). Changing the Attitudes of At risk Students. California Continuation Education Association Newsletter, (2) pp. 4.

Phillips, M., Crouse, J. \& Ralph, J. (1998). Does the Black White Test Score Gap Widen After Children Enter School? In C. Jencks \& M. Phillips (Eds), The Black-White test score gap. pp. 229-272. Washington, DC: Brookings Institution Press.

Pinar, W E, Reynolds, W M., Slattery, P., \& Taubman, P. M. (1995). Understanding Curriculum: An Introduction to the Study of Historical and Contemporary Curriculum Discourses. New York: Peter Lang.

Pincus, B. D., Friedman, G. \& Alice. (December). Improving Children's Coping With Everyday Stress: Transporting Treatment Interventions to the School Setting. Clinical Child and Family Psychology Review. (7), 4.

Pintrich, P. R., and D.H. Schunk. (2003). Motivation in Education: Theory, Research, and Application. Upper Saddle River, NJ: Merrill.

Pogio, A. (2000). Improving Assessment Validity for Students with Disabilities in Large Scale Assessment. Educational Assessment, (10) 4, pp. 357-373.

Pritzlik, U. \& Chan, L. (2004). Children's Self Perception as Reader. Springer Purves, A. (1992). The IEA Study of Written Composition II: Education and Performance in Fourteen Constructs. Oxford, UK: Peragomon press. 
Putting Reading First (2003) The Research Building Blocks of Reading Instruction.

Radcliffe, J., Fleisher, L., Hawkins, A. L., Tanney., Kassam-Adams, N., Ambrose. \& Rudy, B. (2007). Posttraumatic Stress and Trauma History in Adolescents and Young Adults with HIV. Aids Patient Care and STD 'S. (21), 7

Raikes, H., Luze, G., Raikes, A., Pan-Alexander, B., Tamis-Lemonda, C., Constantine, J., Tarullo-Bank, L., \& Rodriguez, E. (2006). Mother-Child Bookreading in Low income Families: Correlates and Outcomes During the First Three Years of Life. Child Development. (77), 4, pp. 924-953.

Reed, V.A. (2005). An Introduction to Children With LanguageDisorders ( ${ }^{\text {rd }}$ ed.). Needham Heights, MA: Allyn \& Bacon.

Reutzel-Ray, D. \& Mitchell, J. (2005). High-stakesAaccountability Themed Issue: How Did We Get Here From There? The Reading Teacher. (58), 7.

Richards, C., Leafstedt, M. L., \& Gerber, M. M,. (2006) Qualitative and Quantitative Examination of Four Low-Performing Kindergarten English Learners:

Characteristics of Responsive and Nonresponsive Students. Remedial and Special Education. (7) 4, pp. 218-234.

Risser, J. H., Hetzel-Riggin., T, J. Cynthia., \& McCanne, R. T. (2006). PTSD As A Mediator of Sexual Revictimization: The Role of Re-experiencing, Avoidance, and Arousal Symptoms. Vol. 19, No. 5.

Roderick, M. (1995). Grade Retention and SchoolDropout: Policy debate and research questions. Phi Delta Kappan Research Bulletin. (15). 
Ross, C., \& Broh, B. (2000). The Roles of Self-Esteem and the Sense of Personal Control in the Academic Achievement. Process Sociology of Education, Vol. 73 No. 4. (Oct, 2000), pp. 270-284.

Ross, S.M., Nunnery, J.A., Goldfeder, F., McDonald, A., \& Rachor, M. (2004). Using school reform models to improve reading achievement: a longitudinal study of direct instruction and success for all in an urban district. Journal of Education for Students Placed At Risk 9 (4): 357-88.

Rumberger, W. R. (2003) The Causes and Consequences of Student Mobility. The Journal of Negro Education. Vol. 72, No. 1.

Rumsey, D,. (2003). Statistics for Dummies. Wiley, Publishing.

Sanacore, J. (2004). Genuine Caring Literacy for African American Children: Educators Who Provide a Caring Environment That Fosters Literacy Learning also Increase the Chances for African American Children to lead meaningful Academic and Personal lives. The Reading Teacher, vol. 57.

Sankofa-Martin, B., Hurley, A. E., Allen, A. B.\& Boykin, A. (2005). Cultural Expression and Black Students' Attitudes Toward High Achievers. The Journal of Psychology. Vol. 139, No. 3 p. 247-259.

Satcher, D. (1998). Bringing the health approach to the problem of suicide: Suicide and Threatening Behavior. NY. Vol. 28 Iss. 4 p. 325.

Sanchez-Ramos, L. \& Nichols, L. (2007). Self-Efficacy of First-Generation and NonFirst Generation College Students: The Relationship with Academic Performance and College Adjustment. Journal of College Counseling. Spring 2007. Volume 10. 
Schunk, D. H. (2000). Learning theories an education perspective, ( $3^{\text {rd }}$ ed.). New Jersey: Prentice-Hall.

Schunk, D.H. (2003). Self-efficacy for reading and writing: Influence of modeling, goal setting, and self-evaluation. Reading and Writing Quarterly 19 (2): 159-72.

Shavelson, J, R. (1996). Statistical Reasoning for the Behavioral Science. Simon and Schuster. Needham Heights, Mass.

Sears, M. (1998). Preparing School Counselor to be Leaders and Advocates: A critical need in the New Millennium. Theory in Practice. Vol. 41, Iss. 3, p. 154-162

Seiler, F., \& Rowhea, E. (2007). The Role of Communal Practices in the Generation of capital Emotional Energy among Urban African American Students in Science Classrooms. Teachers College Record. Volume 109, Number 2, February 2007, pp. 391-419.

Seligman, M. (1975). Helplessness: On Depression, development, and death. San Francisco: W.H. Freeman.

Share, L. D., \& Silva, A. P. (2003) Gender Bias in IQ-Discrepancy and PostDiscrepancy Definitions of Reading Disability. Journal of Learning Disabilities. Vol. 36, no. 1, p. 4-14.

Shaywitz, S. E., Shaywitx, B. A., Fletcher, J.M., \& Escobar, M.D. (1990). Prevalence of reading disability in boys and girls. Journal of Disorders of Communication. Vol, 22 , p. $219-226$.

Shealey-Williams, M., Lue. \& Scott, M. (2006) Why Are All the Black Kids in Special Education? Revisiting the Issue of Disproportionate Representation. Multicultural Perspectives. Vol. 8, No. 2. 
Shelton, H. K., Harold, T. G., Morey-Goeke, C. M., \& Cummings, E. M. (2006) Children's Coping with Marital Conflict: The Role of Conflict Expression and Gender. Vol. 15. No. 2, P. 232-236.

Shippen, E. M., Houchins, E. D., Calhoon, M., Furlow, Carolyn F. \& Sartor, L D. (2006). The Effects of Comprehensive School Reform Models in Reading for Urban Middle School Students with Disabilities. Remedial and Special Education. Vol, 27, Number 6, November/December 2006, p. 322-328.

Simmons, C. D., Kame'enui, B. H., Coyne, D. M., Stoolmiller, M, Edwards-Santoro, L., Smith, B. S., Beck-Thomas, C., \& Kaufman, K. (2007). Attributes of Effective and Efficient Kindergarten Reading Intervention: An Examination of Instruction time and Design Specificity. Journal of Learning Disabilities. Vol 40, no. 4 p. $331-347$

Slavin, R, E., \& Madden N. A. (1989). What works for students at risk: A research synthesis. Educational Leadership, 46 (5), 4-20.

Snow,C.E., Burns, S., \& Griffin, P. (Eds). (1998). Preventing reading difficulties in young students. Washington, DC: National Academy Press.

Sokal, L. \& Katz, H. (2008). Effects of technology and male teachers on boy's reading. Australian Journal of Education. Vol. 52, no. 1, p. 81-92.

Somer, L. C. \& Piliawsky, M. (2004). Preventing School Failure Dropout Prevention among urban, African American Adolescents: Program Evaluation and Practical Implications. Washington: Spring 2004. Vol. 48, Iss. 3; pg. 17, 6 pgs. 
Squires, D. G. \& Kubrin, E. C. (2005). Privileged Places: Race, Uneven Development and the Geography of Opportunity in Urban American. Urban Studies, Vol. 42, No. 1, 47-68.

Stanton-Chapman, L. T., Chapman, A. D., Kaiser, P. A., \& Hancock, B. T. (2004). Cumulative Risk and Low-Income Children's Language Development. Topics in Early Childhood Special Education. Vol 24, No. 4.

Stecker, M. P., Lembke, S. Erica., \& Foegen, A. (2008). Using Progress-Monitoring Data to Improve Instructional Decision Making. Preventing School Failure. Vol. 52, no. 2. Winter 2008 .

Sternberg, R. \& Grigorenko, E. (2000). Teaching for successful intelligence. Upper Saddle River, NJ: Prentice Hall.

Stewart-Taylor, M. Early literacy instruction in the climate of No Child Left Behind. The Reading Teacher, pp. 732-743.

Strong, C. A., Wehby, J., Falk, B. K. \& Lane, L. K. (2004). The Impact of a Structured Reading Curriculum and Repeated Reading on the Performance of Junior High Students With Emotional and Behavioral Disorders. School Psychology Review. Vol 33, No. 4, pp. 561-581.

Szabo, M. S. \& Mokhtari, K. (2004). Developing A Reading Teaching Instrument for Teacher Candidates: A Validation Study. Action in Teacher Education, Vol 3, Fall 2004.

Talbert-Johnson, C. (2004). Structural inequalities and the achievement gap in urban schools. Education and Urban Society, 37(1), 22-36. 
Taylor, D. \& Dorsey, G. (1998). Growing up Literate: Learning From Inner city Families, Winter, 69, Vol. 20, Issue 4, p. 452.

Teale, H. W., Paciaga, A.K. \& Hoffman, L. J. (2007). Beginning Reading Instruction in Urban Schools: The Curriculum Gap Ensures a Continuing Gap. The Reading Teacher, Vol. 61, p. 344-348.

The Greater Louisville Inc. Report on Education. (2003).

The National Commission on Excellence in Education. (1983). A NATION AT RISK:

The Imperative for Educational Reform: A Report to the Nation and the Secretary of Education United States Department of Education.

Thomas, R. C., \& Gadbois, A. Shannon. (2007). Academic Self Handicapping: The Role of Self-Concept Clarity and Student's Learning Strategies. British Journal of Education Psychology. (77) pp. 101-119.

Thompson, B. (2008). Characteristics of Parent Teacher Email Communication. Communication Education. (57), 2 pp. 201-223.

Torgesen, J.K., \& Burgess, S. (1998). Consistency of reading related phonological processes throughout early childhood: Evidence from longitudinal-correctional and instructional studies. In J. Metsala and I. Ehri (EDS), Word recognition in beginning reading pp. 161-188. Hillsdale, NJ: Lawrence Erlbaum Associates. Torgesen, J.K. (2000). Individual differences in response to early interventions in reading; The lingering problem of treatment resisters. Learning Disabilities Research \& Practice (15), pp. 55-64.

Tschannen-Moran, M. \& Woolfolk Hoy, A. (2001). Teacher efficacy: Capturing an elusive construct. Teaching and Teacher Education. (17), pp. 783-805. 
Turner, D. J. (2005). Orchestrating Success for African American Readers: The Case of an Effective Third Grade Teacher. Reading Research and Instruction. (44), 4

Urban League (1999) The State of African American Youth in Metropolitan Louisville.

Louisville Urban League.

U.S. Department of Education. (1998). Turning around low-performing schools: A guide for state and local leaders. Washington, DC: Author.

Unrau, Li, N. J. (2004). Content area reading and writing: Fostering illiteracies in middle and high school cultures. Upper Saddle River, NJ:

Pearson/Merrill/Prentice-Hall.

Unrau, N., \& Schlackman, J. (2006). Motivation and Its Relationship with Reading Achievement in an Urban Middle School. The Journal of Education Research. (100) 21

Valas, H. (2001). Learned helplessness and Psychological Adjustment II: effects of learning disabilities and low achievement. Scandinavian Journal of Educational Research, (45) 2.

Vogt, Paul W. (1999). Dictionary of Statistics and Methodology: A Nontechnical Guide for the Social Sciences.

Vondra, J. L. (1999). Commentary for "Schooling and High-RiskPopulations: The Chicago Longitudinal Study, "Journal of School Psychology, (37) 4, pp. 471-479.

Viadero, Debra. (2003). Education Week. Washington. (23) 2, pp. 10

Viljoen, L., \& O'neil, L. M., \& Sidhu, A. (2005) Bullying Behaviors in Female and Male Adolescent Offenders: Prevalence,Types, and Association with Psychosocial Adjustment, Aggressive Behavior. (31), pp. 521-536. 
Walker, H. M. (1997). The Acting Out Child: Coping with Classroom Disruption $\left(2^{\text {nd }}\right.$ ed.). Longmont, CO: Sopris West.

Welsch, G. R. (2006). 20 Ways to Increase Oral Reading Fluency. Intervention in School and Clinic. (41), 3, pp. 180-183.

Wheldall, K., \& Madelaine, A. (2000). A Curriculum-Based Passage Reading Test for Monitoring the Performance of Low-Progress Readers: The Development of the WARP. International Journal of Disability Development and Education. (47) 4

Wigfield, A., \& Guthrie, J. T. (1997). Relations of children's motivation for reading to the amount and breadth of their reading. Journal of Educational Psychology, (89), pp. 430-432.

Whitford, L. B., \& Jones, Ken. (1997). Kentucky's Conflicting Reform Principles: HighStakes School Accountability and Student Performance Assessment. Phi Delta Kappan. (78).

Wolfe, P., \& Brandt, Ron. (1998). What Do We Know From Brain Research? Education Leadership. (56) 3, pp. 8-13.

Wong, Y. L. (1997). Clearing Hurdles In Teacher Adoption and Sustained Use of Research-Based Instruction. Journal of Learning Disabilities. (30), pp. 482-485.

Worrell, C. F., Roth, A. D. \& Gabelko, H. N. (2007) Elementary Reading Attitude Survey (ERAS) Scores in Academically Talented Students. Roeper Review. (29) 2, pp. $119-124$

Wright, C. \& Diener, M., \& Kay, S. (2000). School Readiness of Low-Income Children At Aisk For School Failure. Journal of Children \& Poverty. (6) 2, pp. 99-117. 
Yeung, W. J. \& Conley, D. (2008). Black-White Achievement and Family Wealth. Child Development. (79) 2, pp. 303-324.

Zeldin, S. (2002). Sense of Community and Positive Adult Beliefs Toward Adolescents and Youth Policy in Urban Neighborhoods and Small Cities. Journal of Youth and Adolescence. (32) 5.

Zigler, E., \& Finn-Stevenson, M. (2007) From Research to Policy and Practice: The School of the $2 I^{\text {st }}$ Century. American Journal of Orthopsychiatry. (77) 2, pp. 175 181. 


\section{APPENDIX A \\ The Reader Self-Perception Scale}

Listed below are statements about reading. Please read each statement carefully. Then circle the letters that show how much you agree or disagree with the statement. Use the following:

$$
\begin{aligned}
\text { SA } & =\text { Strongly Agree } \\
A & =\text { Agree } \\
U & =\text { Undecided } \\
D & =\text { Disagree } \\
S D & =\text { Strongly Disagree }
\end{aligned}
$$

Example: I think pizza with pepperond is the best. $\quad$ SA A U D SD

If you are really positive that pepperoni pizza is best, circle SA (Strongly Agree).

If you think that is good but maybe not great, circle A (Agree).

If you can't decide whether or not it is best, circle $U$ (undecided).

If you think that pepperoni pizza is not all that good, circle D (Disagree).

If you are really positive that pepperoni pizza is not very good, circle SD (Strongly Disagree).

1. I think I am a good reader.

2. I can tell that my teacher likes to listen to me read.

[SF] 3. My teacher thinks that my reading is fine.

[OC] 4. I read faster than other kids.

[PS] 5. I like to read aloud.

$[O C] 6$. When I read, I can figure out words better than other kids.

[SF] 7. My classmates like to listen to me read.

[PS] 8. I feel good inside when I read.

[SF] 9. My classmates think that I read pretty well.

[PR] 10. When I read, I don't have to try as hard as I used to.

[OC] 11. I seem to know more words than other kids when I read.

[SF] 12. People in my family think I am a good reader.

[PR] 13. I am getting better at reading.

[OC] 14. I understand what I read as well as other kids do.

[PR] 15. When I read, I need less help than I used to.

[PS] 16. Reading makes me feel happy inside.

[SF] 17. My teacher thinks I am a good reader.

[PR] 18. Reading is easier for me than it used to be.

[PR] 19. I read faster than I could before.

[OC] 20.1 read better than other kids in my class.
SA A U D SD

SA A U D SD

SA A U D SD

SA A U D SD

SA A U D SD

SA $A$ U $\quad D \quad S D$

SA $A$ U $D$ SD

SA A U D SD

SA A U D SD

SA A U D SD

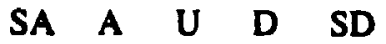

SA A U D SD

SA A U D SD

SA A U D SD

SA $A$ U $\quad$ D $\quad$ SD

SA A U D SD

SA A U D

SA A U D

SA A U D SD

SA A U D SD

(continued) 


\section{APPENDIX A (cont'd.) The Reader Selt-Perception Scale}

[PS] 21. I feel calm when I read.

[OC] 22. I read more than other kids.

[PR] 23. I understand what I read better than I could before.

[PR] 24. I can figure out words better than I could before.

[PS] 25. I feel comfortable when I read.

[PS] 26. I think reading is relaxing.

[PR] 27. I read better now than I could before.

[PR] 28. When I read, I recognize more words than I used to.

[PS] 29. Reading makes me feel good.

[SF] 30. Other kids think I'm a good reader.

[SF] 31. People in my family think I read pretty well.

[PS] 32. I enjoy reading.

[SF] 33. People in my family like to listen to me read.
SA A U D SD

SA A U D $\quad$ SD

SA A U D SD

SA A U D

SA A U D $\quad$ SD

SA A U D $\quad$ SD

SA A U D SD

SA A U D $\quad$ SD

SA A U D SD

SA A U D

SA A U D $\quad$ SD

SA A U D

SA A U D SD 


\section{APPENDIX B \\ The Reader Self-Perception Scale \\ Directions for administration, scoring, and interpretation}

The Reader Self-Perception Scale (RSPS) is intended to provide an assessment of how children feel about themselves as readers. The scale consists of 33 items that assess self-perceptions along four dimensions of self-efficacy (Progress, Observational Comparison, Social Feedback, and Physiological States). Children are asked to indicate how strongly they agree or disagree with each statement on a 5-point scale (5 = Strongly Agree, 1 = Strongly Disagree). The information gained from this scale can be used to devise ways to enhance children's self-esteem in reading and, ideally, to increase their motivation to read. The following directions explain specifically what you are to do.

\section{Administration}

For the results to be of any use, the children must: (a) understand exactly what they are to do, (b) have sufficient time to complete all items, and (c) respond honestly and thoughtfully. Briefly explain to the children that they are being asked to complete a questionnaire about reading. Emphasize that this is not a test and that there are no right answers. Tell them that they should be as honest as possible because their responses will be confidential. Ask the children to fill in their names, grade levels, and classrooms as appropriate. Read the directions aloud and work through the example with the students as a group. Discuss the response options and make sure that all children understand the rating scale before moving on. II is important that children know that they may raise their hands to ask questions about any words or ideas they do not understand.

The children should then read each item and circle their response for the item. They should work at their own pace. Remind the children that they should be sure to respond to all items. When all items are completed, the children should stop, put their pencils down, and wait for further instructions. Care should be taken that children who work more slowly are nol disturbed by children who have already finished.

\section{Scoring}

To score the RSPS, enter the following point values for each response on the RSPS scoring sheet (Strongly Agree = 5, Agree = 4, Undecided = 3. Disagree = 2. Strongly Disagree = 1) for each item number under the appropriate scale. Sum each column to obtain a raw score for each of the four specific scales.

\section{Interpretation}

Each scale is interpreted in relation to its total possible score. For example, because the RSPS uses a 5-point scale and the Progress scale consists of 9 items, the highest total score for Progress is $45(9 \times 5=45)$. Therefore, a score that would fall approximately in the middle of the range (22-23) would indicate a child's somewhat indifferent perception of her or himself as a reader with respect to Progress. Note that each scale has a different possible total raw score (Progress $=45$, Observational Comparison $=30$, Social Feedback $=45$, and Physiological States $=40$ ) and should be interpreted accordingly.

As a further aid to interpretation. Table 2 presents the descriptive statistics by grade level for each scale. The raw score of a group or individual can be compared to that of the pilot study group at each grade level. 


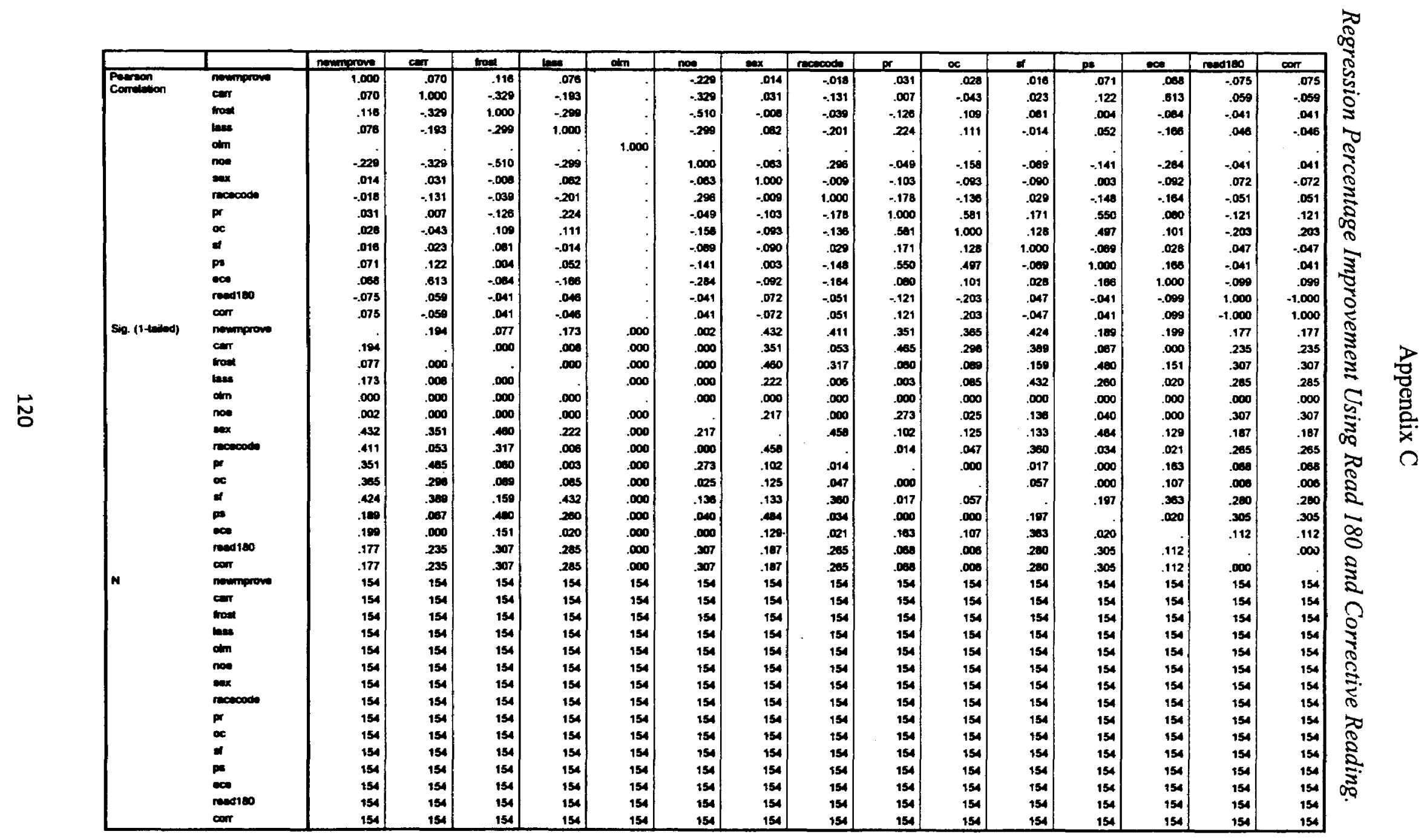




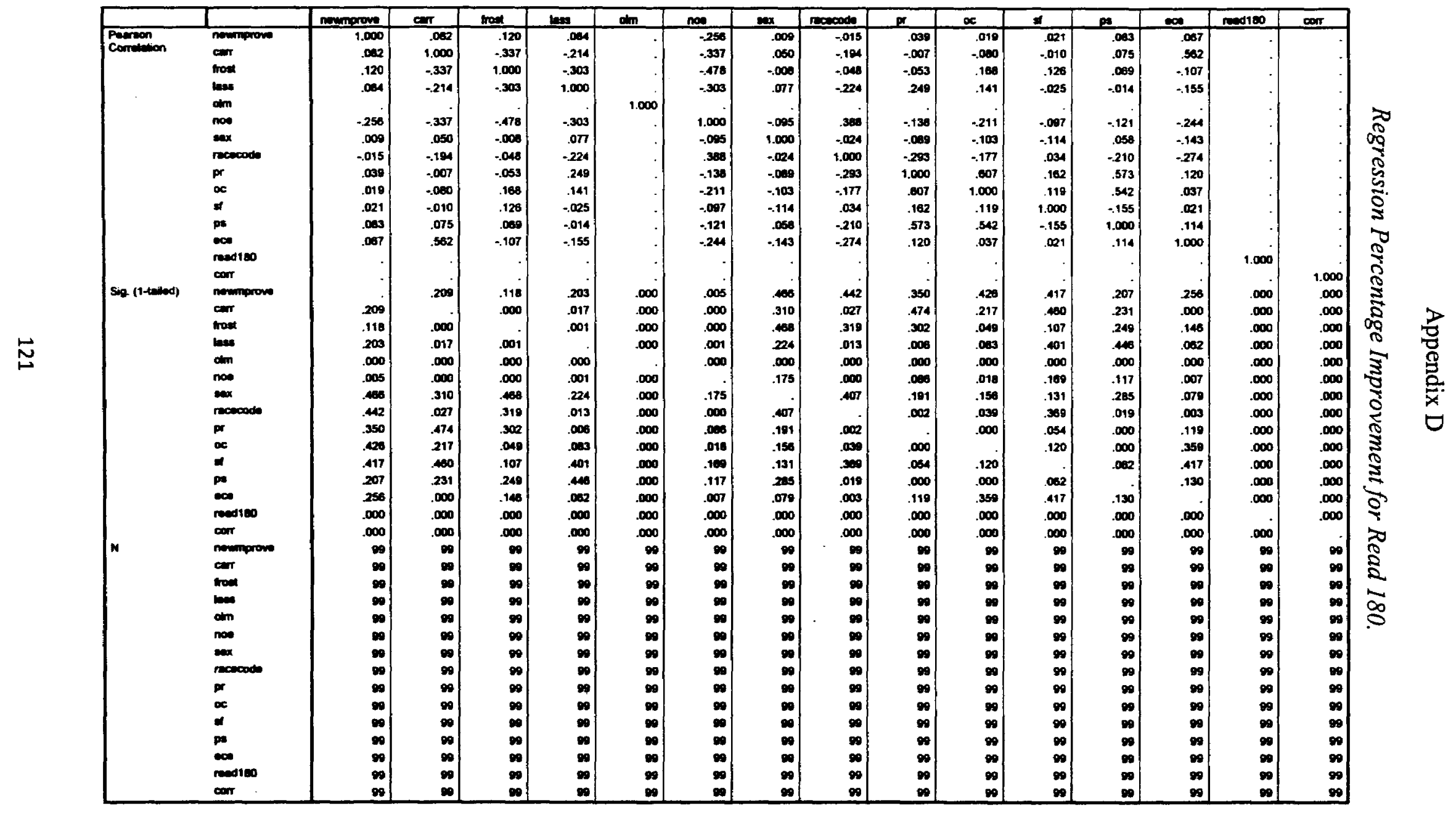




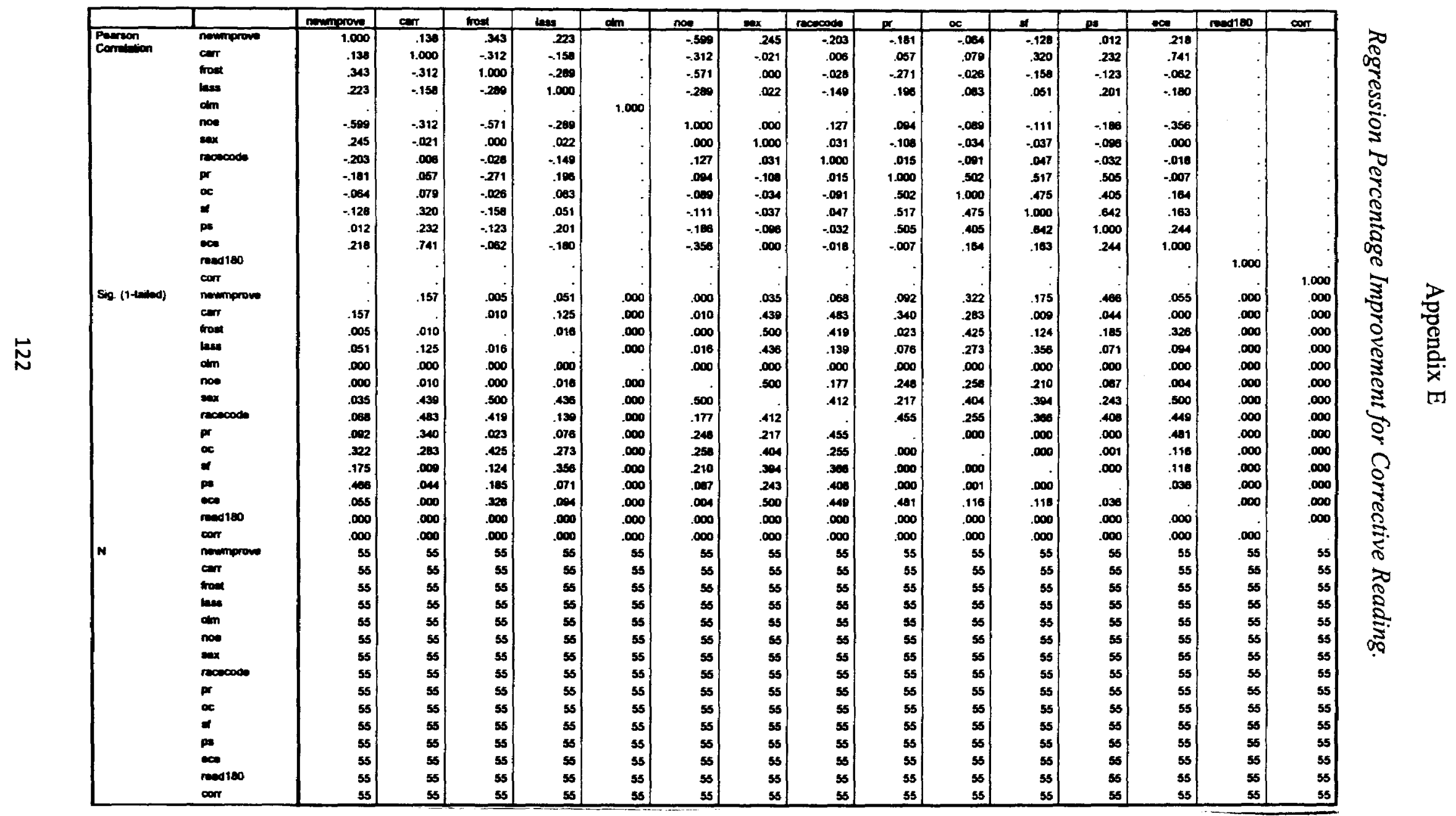




\section{CURRICULUML VITAE \\ Reginald L. Caldwell, Ph.D.}

College of Education

Spalding University

845 S. Fourth Street

Louisville, Kentucky 40202-2188

502 585-9911, ext 2295

Email: rcaldwell@spalding.edu

\section{$\underline{\text { Educational Background }}$}

Ph. D. in Curriculum and Instruction: Specific Learning Disabilities/Emotional Behavior Disorders- Dissertation topic: "A Study of Predictive Factors of Low-Performing Readers in an Urban District.

The University of Louisville, May $9^{\text {th }}, 2009$, Department of Curriculum and Instruction. Areas of specialization: emotional behavior disorders, specific learning disabilities, selfefficacy and reading instruction, diversity in literacy.

M.A. in Special Education: Emotional Behavior Disorders and Specific Learning $\underline{\text { Disabilities }}$

University of Louisville, Louisville, Kentucky, Spring 2000

\section{B.A. English Education}

Talladega College, Talladega, Alabama, 1996
2412 Glenmary \#3

Louisville, KY 40204

305-502-0150

rcaldwe1@aol.com 


\section{Teaching Certifications}

Certified by the State of Alabama to teach middle and high school students (grades 6-12) language arts and English.

Certified by the State of Kentucky to teach middle and high school students (grades K12) Special Education.

Rank I certified by the Commonwealth of Kentucky to teach special education students (grades K-12).

Kentucky Teacher Internship Program Certification (KTIP) to supervise new teacher candidates.

Professional Experience

Assistant Professor of Special Education, Department of Education, Spalding University, Fall 2003-present. Courses taught: Introduction to Special Education, Inclusive Classroom, Methods and Strategies in Behavior Management. Responsible for course preparation including selecting texts, developing course syllabi, presenting lectures, creating and administering tests. Other responsibilities included supervising student interns in field placements, advising, developing partnership with local schools. Participated in PRAXIS workshop trainings that guided new teachers toward initial certification in teaching.

Assistant Director of Alternative Certification Program in Special Education, Spalding University, Fall 2000-present. Assisted in the operations of the program that included 
recruiting, hiring, and supervising adjunct faculty, scheduling classes, and interacting with other administrators and faculty. Department was responsible for preparing new teacher candidates for careers in Special Education (K-12), Middle and Secondary Education (grades 6-12). Assisted in implementing strategies for recruiting diverse faculty and students which resulted in the College of Education programs meeting NCATE Diversity Standard. Further developed partnerships with local schools in assisting with higher graduates from the alternative certification program.

Director of the Minority Teacher Recruitment Project Grant, Spalding University, 20032005. Oversaw the implementation of a grant by the state department of education to recruit middle school students for careers in teaching. Assisted in planning college and university visits, social events for students, and state Future Educators for Tomorrow conferences. Managed fiscal records for the grant.

Adjunct Professor, Alternative Certification Program in Special Education (2+2), Barry University, Miami, Florida, 2001-2003. Course taught: Introduction to Special Education. Responsible for course preparation including developing course syllabi, presenting lectures, creating and administering tests.

English/Reading Teacher, Hallandale High School, Hallandale Beach, Florida. 20002003. Responsible for state accountability standards in English for students grade 9-12. Participated in implementing scientifically researched based reading program for at-risk students.

Special Education EBD/SLD Teacher and Department Head, Meyzeek Middle School, 1998-2000 Louisville, KY. Responsible for implementation of individualized education 
programs for students with emotional behavior disorders and specific learning disabilities. Responsible for program operation and teacher responsibilities for all students.

$\underline{\text { Service to Professional Organizations }}$

University Supervisor for Alternative Certification Program candidates, 2003-present

Council on the Retention of Undergraduate Students Committee Member, 2003

Site Coordinator of TEMP Grant for Minority Teacher Recruitment, 2003-2005

Advisor for the Black Student Union (BSU) Spalding University, 2000

NCATE Committee Member for Spalding University, 2003

Kentucky Long-Term Research and Policy Center Conference, 2000

Kentucky Task Force on Special Education, 2001

Speaker at Canaan Missionary Baptist Church "Minority Teacher Shortage", 2001

Narrator: Louisville MTRP/FEA Conference, Hilton Garden Inn, 2005

The Kentucky Alliance against Racist and Political Repression Conference, 2006

Tenth Annual Race and Relations Conference, 2006

Faculty Search Committee, 2006 \& 2008

Faculty Senate Committee (Alternate) 2006

Library Committee 2006 
Undergraduate Admissions Committee 2007

Research and Ethics committee 2008

Library Committee Chairperson 2008

Organizations

National Education Association 1998-2003

Kappa Alpha Psi Fraternity Incorporated 1994-present

Minority Teacher Recruitment Project 1996-1999

KYNPSC Accreditation Committee 